\title{
Recombination in Enteroviruses, a Multi-Step Modular Evolutionary Process
}

\author{
Claire Muslin ${ }^{1, *} \mathbb{D}$, Alice Mac Kain ${ }^{2}\left(\mathbb{D}\right.$, Maël Bessaud ${ }^{2} \mathbb{D}$, Bruno Blondel $^{3,4}$ and \\ Francis Delpeyroux ${ }^{3,4}$ \\ 1 One Health Research Group, Faculty of Health Sciences, Universidad de las Américas, Quito EC170125, \\ Pichincha, Ecuador \\ 2 Institut Pasteur, Viral Populations and Pathogenesis Unit, CNRS UMR 3569, 75015 Paris, France; \\ alice.mac-kain@pasteur.fr (A.M.K.); mael.bessaud@pasteur.fr (M.B.) \\ 3 Institut Pasteur, Biology of Enteric Viruses Unit, 75015 Paris, France; bruno.blondel@pasteur.fr (B.B.); \\ francis.delpeyroux@pasteur.fr (F.D.) \\ 4 INSERM U994, Institut National de la Santé et de la Recherche Médicale, 75015 Paris, France \\ * Correspondence: claire.muslin@udla.edu.ec
}

Received: 6 August 2019; Accepted: 6 September 2019; Published: 14 September 2019

\begin{abstract}
RNA recombination is a major driving force in the evolution and genetic architecture shaping of enteroviruses. In particular, intertypic recombination is implicated in the emergence of most pathogenic circulating vaccine-derived polioviruses, which have caused numerous outbreaks of paralytic poliomyelitis worldwide. Recent experimental studies that relied on recombination cellular systems mimicking natural genetic exchanges between enteroviruses provided new insights into the molecular mechanisms of enterovirus recombination and enabled to define a new model of genetic plasticity for enteroviruses. Homologous intertypic recombinant enteroviruses that were observed in nature would be the final products of a multi-step process, during which precursor nonhomologous recombinant genomes are generated through an initial inter-genomic RNA recombination event and can then evolve into a diversity of fitter homologous recombinant genomes over subsequent intra-genomic rearrangements. Moreover, these experimental studies demonstrated that the enterovirus genome could be defined as a combination of genomic modules that can be preferentially exchanged through recombination, and enabled defining the boundaries of these recombination modules. These results provided the first experimental evidence supporting the theoretical model of enterovirus modular evolution previously elaborated from phylogenetic studies of circulating enterovirus strains. This review summarizes our current knowledge regarding the mechanisms of recombination in enteroviruses and presents a new evolutionary process that may apply to other RNA viruses.
\end{abstract}

Keywords: RNA virus; recombination; emergence; enterovirus; viral evolution

\section{Introduction}

Enteroviruses (EVs) constitute a large genus of small RNA viruses within the Picornaviridae family. This viral family represents one of the widest groups of human and animal viruses and it contains several mammal pathogens, like hepatitis A virus, foot and mouth disease virus, rhinoviruses (RVs), and poliovirus (PV), the etiological agent of poliomyelitis and prototype of EVs. Among the 15 species constituting the Enterovirus genus, seven contain human viruses: Enterovirus $A$ to $D$ (EV-A to -D) and Rhinovirus $A$ to $C$ (RV-A to C) [1].

Infections with human EVs are very common. They most frequently occur in children under the age of 10 and are most often asymptomatic [2]. EVs are characterized by a great phenotypic variability. 
Over 20 clinically recognized syndromes have been frequently associated with human EVs. Among the most frequent are pathologies of the central nervous system (CNS): poliomyelitis, encephalitis, and meningitis [3-6]. More than 90\% of viral meningitis cases are caused by EVs. Enteroviral encephalitis and myelitis are less common, but more often have severe manifestations. Following the elimination of wild type PV in most regions of the world, EV-A type 71 (EV-A71) emerged as the most significant neurotropic EV. EVs are also frequently associated with acute pericarditis and myocarditis, hand-foot-and-mouth disease, pleurodynia, or respiratory disease [7-11]. RVs represent the principal cause of the common cold, a frequent infection both in children and adults, usually limited to the upper respiratory airways $[8,10]$. The three types of PV belong to the EV-C species, which also includes many weakly or non-pathogenic coxsackieviruses A (CV-A), such as CV-A13 or CV-A17.

EVs are small non-enveloped viruses containing a single positive-strand RNA genome of approximately $7.5 \mathrm{~kb}$ in length. This genome encodes a large open reading frame (ORF) that is translated into a polyprotein processed by viral proteases $(2 \mathrm{~A}, 3 \mathrm{C}$, and $3 \mathrm{CD}$ ) to yield four capsid proteins (VP1-4) and non-structural proteins, such as proteases and the RNA-dependent RNA polymerase (RdRp) 3D, which are involved in the viral multiplication and the control of the cellular environment (Figure 1). Viral replication cycles entirely occur in the cytoplasm of infected cells [12]. It was recently demonstrated that the majority of EV-A and EV-B genomes and around half the EV-C genomes contain a second ORF located upstream and overlapping the polyprotein ORF (ppORF) [13]. This second upstream ORF ( $\mathrm{uORF}$ ) encodes a single protein that may play a role in virus growth in gut epithelial cells, which are the entry site of these viruses into a susceptible host. Two untranslated regions flank the coding region of EV genome (5' and $3^{\prime}$ UTR). The EV 5' UTR is about 740 nucleotides in length and it contains seven highly conserved stem-loop domains (I to VII) forming two functional units (Figure 1). Domain I forms a cloverleaf (CL) structure that is required for initiating both negative- and positive-strand RNA synthesis [14-17]. Domains II to VI (dII to dVI) contain the internal ribosome entry site (IRES) that initiates cap-independent translation by interacting with canonical and noncanonical cellular translation factors to recruit ribosomes $[18,19]$. The CL and IRES elements are separated by a short pyrimidine-rich sequence, named spacer 1, and the IRES is linked to the initiation AUG codon of the ppORF by dVII and a poorly structured sequence of about 100 nucleotides, named spacer 2 [20]. This dVII-spacer 2 region contains the main part of the uORF that is present in many EV genomes [13].

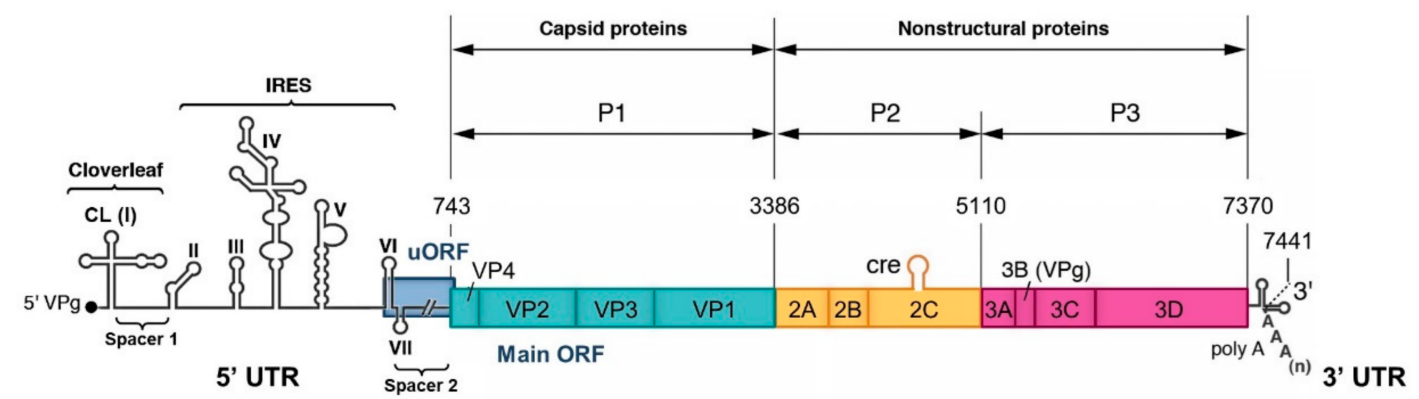

Figure 1. Organization of the genome of poliovirus type 1 (PV1) Mahoney. The poly-adenylated single positive-strand RNA genome is covalently linked to the viral protein VPg (also named 3B) at the $5^{\prime}$ terminus. In addition to the main large open-reading frame (ORF), the majority of the EV-A, EV-B and EV-C genomes, and in particular PV1 genome, contain a second upstream overlapping ORF (uORF). However, PV2 and PV3 genomes do not contain an intact uORF. The coding region is flanked by two untranslated regions (5' and $3^{\prime}$ UTRs). The $5^{\prime}$ UTR (nucleotides 1 to 743) is magnified to indicate the seven stem-loop structures (I to VII) forming two functional units, the cloverleaf (CL: I) and the internal ribosome entry site (IRES: II-VI). The P1 region encodes the capsid proteins (VP1-4) and the P2 and P3 regions encode the non-structural proteins such as the RNA-dependent RNA polymerase 3D.

EV transmission is generally by fecal-oral contamination or by respiratory droplets. In the case of the EVs transmitted by the fecal-oral route, such as PV, viral particles infect the oropharyngeal 
and intestinal mucosa. The virus efficiently multiplies in the intestine and it is excreted in stools for several weeks. From the digestive tract, the EV reaches cervical and mesenteric lymph nodes and then establishes a primary viremia. The infection usually comes to an end at this stage, and therefore most of EV infections are asymptomatic. However, the virus might reach other tissues and organs, depending on his tropism, which results in a secondary viremia and the possible development of syndromes [2]. $\mathrm{PV}$ invades the CNS, its target organ, in less than $1 \%$ of infection. The virus specifically infects and destroys motor neurons, inducing the irreversible flaccid paralyses that are typical of poliomyelitis [21].

As RNA viruses, EVs are characterized by a great genetic variability relying on two different evolutionary mechanisms: mutation and recombination. Firstly, the lack of proofreading activity of the 3D polymerase leads to a high mutation rate and the generation of a population of related sequences, named quasispecies [22]. The extent of this mutant swarm is crucial for viral adaptability, dissemination, and pathogenesis [23-27]. The other major driving force in RNA virus evolution is genomic RNA recombination. RNA recombination is a molecular process, during which genomic fragments that belong to distinct RNA strands are combined in a single genome. Recombination is classified regarding the features of the recombination site of the produced genome, without prior knowledge of the underlying generation mechanism (Figure 2) [28]:

- Homologous recombination occurs at the same site in both parental genomes, therefore no insertion or deletion is observed at the recombination site when the recombinant genome is aligned with parental genomes.

- Nonhomologous recombination occurs at different sites in the two involved genetic fragments, generating aberrant structures, such as deletions or duplications of homologous parental sequences on each side of the recombination site.

Moreover, depending on the origin of the parental strands, we can distinguish between intra-genomic recombination, or rearrangement, wherein the recombining strands belong to the same molecule, and inter-genomic recombination, wherein the fragments have different origins [29].

Homologous recombination
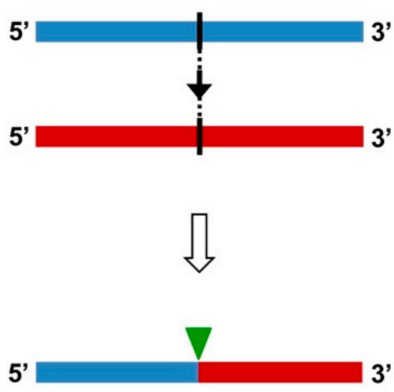

(a)

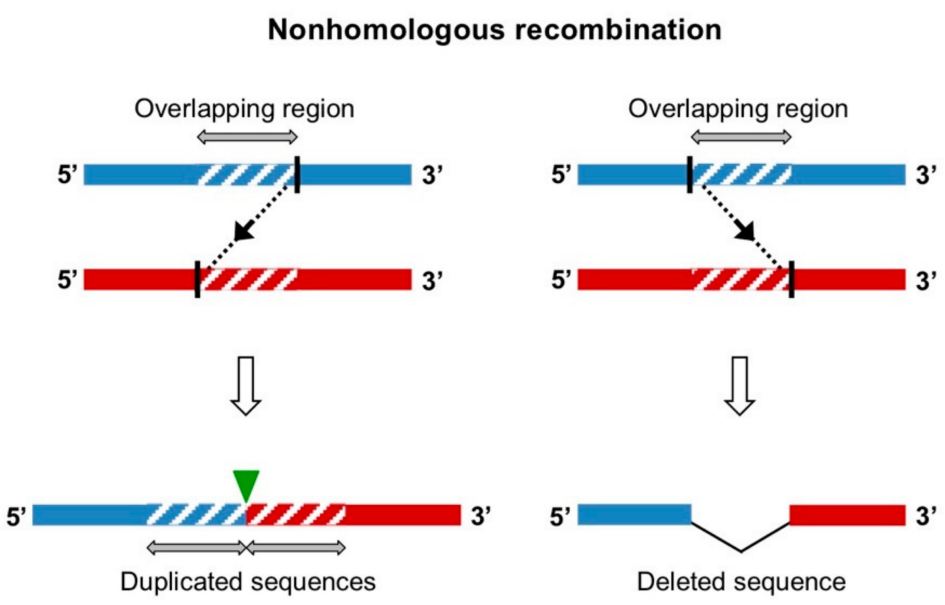

(b) (c)

Figure 2. Homologous and nonhomologous recombinant genomes. Parental RNA genomes are located in the upper panel of (a), (b) and (c) diagrams. They have a similar genomic structure. The recombination site in each of the parental genomes is represented by a black vertical line, the recombination event is indicated by black dotted line and arrow. The recombination site in the obtained recombinant genome (lower panels) of (a) and (b) diagrams is indicated by a green reversed triangle. (a) Homologous recombination occurs at the same site in both parental genomes, thus the obtained recombinant has the same genomic structure as the parental viruses. (b) and (c) Nonhomologous recombination occurs at different sites in the two parental genomes. (b) a duplication of homologous sequences (hatched) is generated around the recombination site. (c) A deletion of genomic sequence is generated. 
RNA recombination allows for the exchange of genetic information and incorporates viral RNA fragments into new genomic contexts. Thus, it favors both the combination of beneficial mutations into the same genome, leading to the creation of variants that are best adapted to withstand environmental selective pressure, and the elimination of negative combinations of mutants from the population [30]. RNA recombination enables viruses to quickly explore a greater proportion of the sequence space than is accessible by point mutations [31]. In addition to being a source of genetic diversity, RNA recombination has been shown to be a repair mechanism, essential to maintain viral genome integrity [32-34]. Recent studies in PV demonstrated that effective RNA recombination is critical to rapid adaptation to dynamic selective environments and that, in the infected host, the concerted activities of mutation and recombination are required to overcome tissue-type specific antiviral selection and to establish robust infection and virulence [35,36].

As an adaptive mechanism, RNA recombination has played an important role in the diversification and evolution of RNA viruses, and resulted in new isolates, lineages, species, or even new families [37-43]. Naturally occurring recombination events between viruses from different families that led to the transfer of a functional RNA element or gene sequence and then resulted in a gain of function have also been described [44-46]. Moreover, RNA recombination has been associated with cross-species transmission and the expansion of viral host range [47-51]. Finally, RNA recombination can lead to an increase of viral pathogenicity [52-54] and fitness [55-58].

In particular, RNA recombination is thought to contribute to the emergence of pathogenic circulating vaccine-derived PVs (cVDPVs) that have been complicating the World Health Organization program for the global eradication of poliomyelitis. This eradication program, which was launched in 1988 and has been largely successful, mainly involved massive vaccination campaigns with the oral polio vaccine (OPV), which is composed of live attenuated strains of the three PV types, Sabin 1,2 , and 3 . These strains are only able to replicate to high titers in the digestive tract, conferring strong systemic and intestinal immunity that limits subsequent PV replication and viral transmission among humans [59]. However, the OPV strains are inherently genetically unstable and suboptimal vaccine coverage may allow for their circulation among humans not adequately immunized with OPV, which leads to genetic drift and the emergence of new pathogenic strains, known as cVDPVs [60-63]. Since 2000, cVDPVs have caused nearly 30 poliomyelitis outbreaks worldwide [64]. Most cVDPVs studied to date have recombinant genomes, composed of sequences that are derived from the OPV strain, with more than $1 \%$ nucleotide substitution, for at least the region encoding capsid proteins and sequences originating from other EV-Cs, especially from CV-A13 and CV-A17 types, for some or all of the rest of the genome, in particular the region encoding non-structural proteins [61,65-73]. By facilitating the replacement of attenuating vaccine sequences in a single event, RNA recombination was found to influence the phenotypic characteristics of the cVDPVs, including their fitness and pathogenicity [74-78].

This review first focuses on the studies of circulating EV strains that led to the elaboration of a theoretical model of EV evolution that is based on highly frequent recombination involving exchanges of functional genetic modules. Subsequently, after describing the two mechanisms of RNA recombination, we present the systems that have been recently used to experimentally study intraand intertypic EV recombination. The experimental results suggest, firstly, that EV recombination is a multi-step process and, secondly, that it occurs at preferential sites along the genome, thus supporting the theoretical model of EV evolution through modular intertypic recombination.

\section{Theoretical Model of Enterovirus Evolution Through Modular Intertypic Recombination}

\subsection{High Recombination Frequency in Enteroviruses}

RNA recombination appears to occur extremely frequently in EVs. Recombination frequencies of $10^{-6}$ per site per generation were estimated during co-infection experiments [74,79]. In the EV-infected population, the recombinant forms are regularly identified, resulting from genetic exchanges 
between viral strains within the same type, between different types within the same species, or even between different species in the case of recombination occurring in the $5^{\prime}$ UTR [80-90]. This high naturally-occurring recombination frequency is partly due to the fact that EVs display several ecological and biological features that were identified as being necessary for the occurrence of genetic exchanges and the emergence of viable recombinant viruses [28,91]:

- Co-circulation: Several studies evaluating the circulation and genetic diversity of EVs in restricted geographic areas and on a short period of time revealed an extensive co-circulation of a high number of types from the four human EV species, usually associated with a high intra- and intertypic recombination frequency [65,92-97].Host co-infection: Consistent with the intense co-circulation observed, many cases of multiple infections in individuals have been reported $[65,80,98]$.

- Cell co-infection: It was recently demonstrated that PV can spread as one unit containing multiple viral particles, either within lipid vesicles or as viral aggregates, and this delivery mode increased coinfection frequency and infectivity $[99,100]$. Furthermore, another recent study showed that certain resident bacteria of the gastrointestinal tract bind PV, increase viral co-infection of mammalian cells and enhance viral recombination, even when the ratio of virus to host cells is low, such as during the first cycle of replication following inter-host transmission [58].

- Colocalization of parental genomes: As all positive-strand RNA viruses, EVs replicate their genomes in virus-induced, membrane-bound replication compartments. The study of cells co-infected with two different PV strains showed that the majority of replication complexes contained both viral genomes, early in infection [101]. Moreover, a recent study in Brome mosaic virus (BMV) showed that the structure and size of the virus membranous replication compartments play a fundamental role on recruitment of multiple RNAs into a contiguous space, and thus on inter-genomic RNA recombination frequency, and accordingly suggested that the PV replication structures might favor RNA recombination [102,103].

- Selection: Finally, generated recombinant genomes have to be viable and able to efficiently compete with parental genomes and to confront bottleneck events occurring during virus life cycle, to spread in the viral population. This implies a structural and functional compatibility of the different recombining sequences, as well as a certain tolerance to genomic alterations in order to limit their negative consequences.

\subsection{Analysis of Recombination Events in Circulating Enterovirus Strains}

The first phylogenetic analysis of complete genomes of EV prototype strains highlighted the significant role of recombination in the evolution of the human EV species [104]. The results of intraspecies comparisons by bootstrap and genetic similarity analyses provided strong evidence that multiple homologous recombination events, both within and between types, which led to the shuffling of genomic fragments between various strains, had shaped the evolution of each EV species. Moreover, the study suggested that two early recombination events at the junction of the $5^{\prime}$ UTR and coding region of the species progenitors could explain that current human EV 5' UTR sequences cluster into two distinct major phylogenetic groups: group I, which is comprised of EV-C and EV-D, and group II, which is formed by EV-A and EV-B. This work was the first one to suggest the concept of independent evolution of different genome fragments. Thereafter, these results were confirmed by several studies that analyzed and compared the phylogenetic relationships in different genomic regions of prototype and field strains $[80,81,83-85,87,105-108]$. Within each human EV species, radical incongruent tree topologies between the untranslated, structural and non-structural regions, and even between different proteins across the non-structural region of the genome, indicated frequent intraand intertypic recombination during the evolution of EV types. Such studies provided evidence that RNA recombination had played an important role for EV speciation and it remains a major driving force in the ongoing evolution of EVs within each species.

Full-genome comparisons and sequence similarity analyses of prototype and circulating EV strains led to the suggestion that genetic restrictions might influence the recombination location 
and frequency $[86,104,109-111]$. Firstly, the junctions between the $5^{\prime}$ UTR and the structural region and between the structural and non-structural regions were identified as putative recombination hotspots, flanking a structural region where recombination was virtually absent. Indeed, although EVs displaying chimeric capsid proteins have been documented [112-115], intertypic recombination events appeared to occur almost entirely outside of the capsid-encoding region $[86,107,108,116]$, which suggests that it is a relatively stable unit. This could be explained by structural incompatibilities between capsid proteins from different types during virus assembly or maturation, or during receptor binding, when the parental viruses use different receptors $[107,111]$. By contrast, multiple studies provided evidence of the occurrence of extensive series of recombination events throughout the entire non-structural region, which seemed to be relatively randomly distributed and resulted in complex mosaics of sequences $[86,104,108-111,117]$. These observations suggest that each non-structural protein might be functionally interchangeable with any other variant within each species. Secondly, recombination appears to only occur among members of a given species. The frequency and dynamics of recombination seemed to be different between the human EV species [109,111]. For example, time-correlated recombination events might be more frequent in EV-B than in other human EV species [111]. Moreover, within each human EV species, type-specific recombination frequencies have been observed, with a few types functioning as preferential recombination partners $[84,86,108,118]$. Subgroups within a given species could also be defined, depending on recombination dynamics [119].

\subsection{Genetic Features of Recombinant Circulating Vaccine-Derived Poliovirus Genomes}

Most of the cVDPVs described so far have mosaic genomes that are composed of mutated OPV sequences and sequences related to non-PV EV-Cs [61]. The analysis of the cVDPV strains implicated in outbreaks of poliomyelitis in Cambodia [120] and Madagascar [65,70] revealed that the non-PV EV-C sequences that are present in the genomes of these strains were related to co-circulating non-pathogenic CV-A strains, especially from CV-A13 and CV-A17 types. Several closely related EV-C types are actually thought to be able to function as recombination partners for OPV strains [108]. Thus, the multiplication and circulation of OPV strains in close interaction with other EV-Cs within a diverse EV ecosystem led to exchanges of genetic fragments through intertypic recombination and the emergence of these cVDPV strains $[65,70,86]$.

Moreover, most of the recombinant cVDPV genomes studied to date displayed similar genetic patterns. They were homologous recombinants that had kept at least the entire structural region of OPV strains, with more than $1 \%$ nucleotide substitutions, and some or all of the $3^{\prime}$ half of the genome was derived from non-PV EV-C sequences. In most of them, the recombination sites were located in proteins $2 \mathrm{~A}$ or $2 \mathrm{~B}$ (Figure 3 ) $[65,67-69,73,120]$. Nevertheless, recombination sites could also be found elsewhere in the non-structural region $[66,70,71]$. In addition, many VDPV lineages also displayed a $5^{\prime}$ UTR that was acquired by intertypic recombination [66,70-73]. Thus, most of the cVDPV genomes resulted from the association of several genetic segments from different phylogenetic origins. cVDPV genomic structures could be highly complex, as some cVDPV lineages showed quadripartite recombinant genomes between OPV and non-PV EV-C sequences [70]. The location of the recombination sites, delimiting the genetic segments, matched the preferential recombination regions that were identified by the phylogenetic studies presented previously: the two extremities of the structural region and the entire non-structural region (Figure 3). 




Figure 3. Genomic structures of all recombinant circulating vaccine-derived poliovirus lineages characterized so far. A schematic view of the genetic organization of the poliovirus genomes is given in the upper panel (see also Figure 1). The presence of vaccine-derived sequences is indicated (mutated Sabin 1,2 , of 3 sequences) as well as the non-vaccine sequences derived from other species $C$ enteroviruses (EV-Cs). Colors and patterns differentiate EV-C sequences that differed significantly from each other. Non-vaccine sequences showing similarity with those of co-circulating coxsackieviruses A (CV-A11, -A13, -A17) are indicated. Data are modified from [73] (Egypt), [67] (Greece), [68] (Hispaniola), [69] (Philippines), [71,72] (Nigeria), [65,66,70,76] (Madagascar), [120] (Cambodia). The location of the six recombinant hotspots identified by experimental studies of genetic exchanges between poliovirus and enteroviruses is indicated by grey rectangles $[77,121,122]$ (see further in the text). 


\subsection{Modular Intertypic Recombination Hypothesis}

Genomic and phylogenetic analyses of EV strains from the four human EV species, including cVDPVs, highlighted the essential role of recombination in the evolution and the genetic architecture shaping of EVs. It became clear that the type classification that is used for EVs and based on the degree of similarity between the strains in the region encoding capsid proteins is generally not reflected in the non-structural region and the 5' UTR [104]. EV genome seems to be constituted of different genetic fragments that follow different evolutionary paths. Indeed, while the range of EV types circulating in human population, often episodically, remains relatively constant, the accumulated set of distinct genetic lineages of 3D polymerase encoding sequences is far greater and their occurrence far more transitory [123]. The location of the putative recombination sites, delimiting the genomic fragments, suggest that the $5^{\prime}$ UTR and the capsid-encoding region could both be considered as recombination units within which recombination is probably constrained by genetic and/or structural requirements, unlike the non-structural region, where each protein-coding sequence could be exchanged as a single unit $[107,108]$.

These observations led to the elaboration of a theoretical model of EV genetics. EV types cannot be considered as "subspecies" with independent evolutionary patterns, but rather EV species would consist of a finite set of capsid genes that are responsible for different types and a swarm of non-structural protein genes and untranslated regions $[83,106,110]$. These different genomic fragments would evolve independently and combine freely and frequently through RNA recombination during co-infections, potentially producing variants with new phenotypic properties. This mode of evolution through modular recombination would provide a high level of flexibility and a capacity for very quick evolutionary changes to the EVs, and could be viewed in particular as an adaptative response to the immune system of their hosts [106].

\section{Two Main Mechanisms of RNA Recombination in Enteroviruses}

Two different mechanisms can lead to the generation of a recombinant RNA molecule in RNA viruses, including EVs: the replicative "copy-choice" mechanism and the nonreplicative "breakage-ligation" mechanism (Figure 4). Both were first described in PV [79,124].

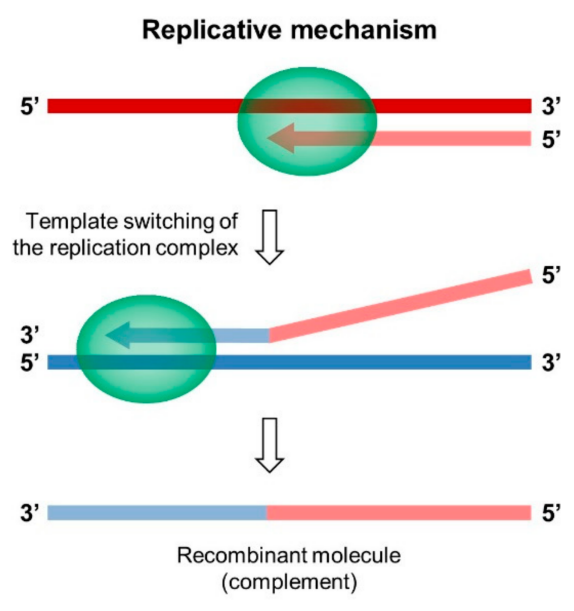

(a)

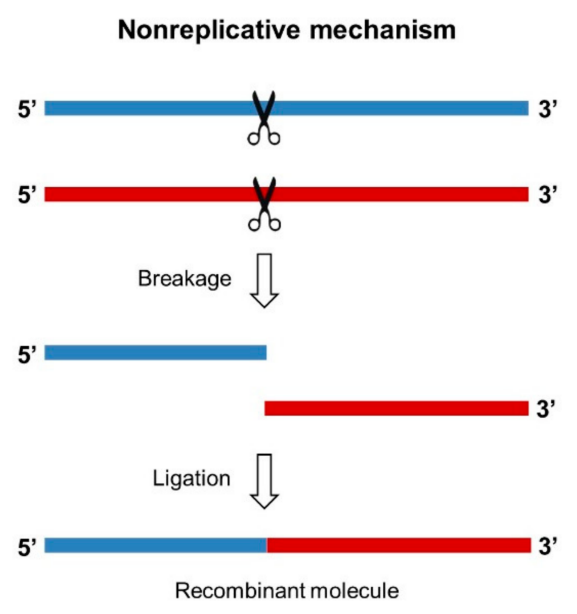

(b)

Figure 4. Mechanisms of replicative and nonreplicative RNA recombination. (a) The replicative mechanism of copy-choice. The replication complex pauses during the synthesis of the complementary strand of the RNA donor (in red) and dissociates from the RNA donor template. Then, the incomplete nascent RNA strand interacts with the acceptor RNA (in blue) where the replication complex reassembles and the synthesis of the complementary strand resumes. The complementary strand is indicated by lighter colors. (b) The nonreplicative mechanism of breakage-ligation. The two parental RNA molecules are degraded, and then the two fragments generated are covalently linked. 


\subsection{The Replicative Mechanism of Copy-Choice}

The copy-choice has been demonstrated in many RNA viruses, including retroviruses, and it is considered as the major viral RNA recombination mechanism $[30,125,126]$.

\subsubsection{Template Switching of the Viral Polymerase}

The model that was proposed for the copy-choice mechanism postulates that the neo-synthesized nucleic acid chain can dissociate from the RNA donor template during replication and interact with a different template, the acceptor RNA, or with a different region of the same template. This interaction results in the transfer of the replication complex to the new template, where RNA synthesis resumes, which produces a hybrid genomic molecule that contains genetic information from two different sources (Figure 4a) [28,79]. Template switching can produce homologous, as well as nonhomologous, recombinants.

The first experimental evidence supporting the copy-choice mechanism was provided in 1986 by Kirkegaard and Baltimore, despite being initially proposed by Cooper et al. as a model of recombination in PV [127], who demonstrated that RNA synthesis was necessary for PV recombination [79]. Following this study, the replicative copy-choice model could be confirmed and generalized to other RNA viruses and retroviruses, and many studies tried to characterize the details of its molecular mechanism $[125,128,129]$. The template switching capacity of the PV 3D polymerase was demonstrated while using purified reconstituted in vitro systems [130]. The possibility for the 3D polymerase to use the $3^{\prime}$ end of the incomplete nascent RNA strand as a primer to be elongated on a new template was also confirmed [131-133]. The identification of mutations in the 3D polymerase that negatively or positively affect recombination frequency further supported the replicative recombination mechanism [35,121,134,135].

Nevertheless, the exact molecular mechanism of the copy-choice remains to be elucidated. For that matter, different mechanisms may exist according to the features of the viral polymerase and replication complex, or else, several mechanisms might be possible for a single polymerase. Distinct possible mechanisms have been postulated $[125,135,136]$ : (i) the elongation complex dissociates from the RNA donor template and the polymerase-incomplete nascent RNA strand complex interacts with a new template, the acceptor RNA; (ii) the incomplete nascent RNA strand alone dissociates from the elongation complex, interacts with the acceptor RNA, and recruits a new polymerase; (iii) the incomplete nascent RNA strand dissociates, leaving the polymerase-RNA donor template complex that associates with a new incomplete nascent strand; and, (iv) the RNA donor and acceptor templates closely hybridize and template switching occurs without dissociation of the elongation complex. In the case of PV, recent findings by Kempf et al. on the structure of the 3D polymerase and the elongation complex seem to favor the second possibility mentioned above [135]. The identification of regions that are capable of forming stable heteroduplexes at the vicinity of certain recombination sites in PV genome suggested that the fourth mechanism mentioned above could also be implicated in some cases $[125,137]$.

Finally, for some positive-strand RNA viruses, including PV, it was postulated that template switching preferentially occurs during negative-strand RNA synthesis $[79,138,139]$, whereas, for other viruses, it would either preferentially occur during positive-strand RNA synthesis $[140,141]$ or indifferently between either strand [142,143].

\subsubsection{Factors Influencing Template Switching}

Many factors are supposed to favor template switching, by having an effect on the pausing of the synthesis on the donor strand, which destabilizes the replication complex and promotes its dissociation, or by playing a role in the association of the nascent strand and the polymerase to the acceptor RNA.

The high replication speed of RdRps, as optimized by natural selection, results in a high incorporation of incorrect nucleoside triphosphates (NTPs), which is associated with an increased 
number of pause events that may favor elongation complex dissociation [144-147]. Stable secondary, or even tertiary, structural features in the donor RNA molecule were described in many RNA viruses as a critical factor for the slowing and destabilization of the elongation complex [148-151]. In particular, secondary structures were identified as recombination hotspots in PV genome [152-154]. Various other factors were found to promote template switching, including heteroduplex formation between parental RNAs [139,155-158], the presence of breaks in the RNA template $[128,149]$, and low NTP concentrations [159]. Finally, recombination sites were often found to be associated with AU-rich sequences in several positive-strand RNA viruses, including PV [30,139,160-163]. The weak annealing of A-U nucleotides is supposed to facilitate the dissociation of the nascent strand from the complementary donor strand inside the replication complex, and thus the template switching initiation.

After dissociation from the donor template, the replication complex and the nascent strand need to bind the acceptor template to re-initiate nucleic acid synthesis. The first feature identified as a factor that affects recombination frequency and location is the sequence identity level between the nascent strand and the acceptor RNA [125,129]. Indeed, many studies in PV and other positive-strand RNA viruses showed a direct correlation between the degree of sequence identity of the templates and the recombination frequency $[79,121,164,165]$. The sequence identity level between the nascent and acceptor strands is also thought to promote homologous recombination, by enabling the two strands to extensively dimerize and induce a precise strand switch [28]. Moreover, in the case of PV and BMV, GC-rich sequences could be associated with an increase of recombination frequency in the vicinity of these sequences and are thought to promote the annealing of the incomplete nascent RNA strand to the acceptor RNA template [153,161]. This interpretation suggests that, in these viruses, thermodynamic factors influence the annealing of the nascent strand to the acceptor RNA to a greater extent than the initial dissociation from the donor template, which is conversely hampered by the strong annealing of G-C nucleotides [153].

Host and environmental factors are also supposed to be implicated in the copy-choice mechanism. Studies in tombusvirus and hypovirus led to the identification of various cellular pathways and factors that are involved in viral replicative RNA recombination [166-170].

\subsection{The Nonreplicative Mechanism of Breakage-Ligation}

\subsubsection{Demonstration in Poliovirus}

An alternative recombination model that is fundamentally different from the copy-choice was first advanced on the basis of experimental data obtained in a cell-free system that employed purified bacteriophage $Q \beta$ replicase to detect replicable RNAs that were generated from nonreplicable RNA fragments [171,172]. However, the presence of $Q \beta$ replicase required for amplification of the recombinant molecules did not fully exclude a replicative mechanism.

Following these studies, the existence of a recombination mechanism not involving the viral polymerase was unambiguously demonstrated in vivo in PV while using pairs of defective complementary genomic RNA fragments $[124,136,173]$. The transcript containing the functional $5^{\prime}$ part of the viral genome is called 5' partner, the one providing the functional $3^{\prime}$ part is the $3^{\prime}$ partner. In a first pair configuration, the $5^{\prime}$ partner comprised the entire $5^{\prime}$ UTR only and the $3^{\prime}$ partner was made from the complete PV genome, in which the IRES was mutated or deleted [124]. Co-transfecting cells with these two complementary genomic RNA fragments that are unable to be translated or to replicate led to the production of infectious genomes that are recombinant in the dVII-spacer 2 region linking the $5^{\prime}$ UTR to the ppORF. Homologous as well as nonhomologous recombinant genomes were isolated in this highly permissive genomic region. These results suggested that RNA recombination could occur in the absence of a functional RdRp.

This hypothesis was confirmed even more rigorously with another pair configuration, in which the two RNA fragments corresponded to the PV genome with a break in the RdRp-coding region [173]. Since each fragment only contained a part of the viral RdRp gene, this enzyme could not be involved in 
the first steps of the generation of the recombinant molecule. In the case of RNA partners supplementing each other precisely, a single ligation by phosphodiester bond would restore the integrity of the PV genome. Co-transfecting cells with this partner pair only yielded viable viruses when the $5^{\prime}$ partner contained a phosphorylated $3^{\prime}$-nucleotide (3'-P) and the $3^{\prime}$ partner harbored a $5^{\prime}$ hydroxyl group $\left(5^{\prime}-\mathrm{OH}\right)$. In the case of overlapping RNA fragments, a majority of homologous recombinant genomes were isolated, and an association was observed between the recombination site location and the terminal nucleotide structure of both partners. When the cells were co-transfected with unmodified RNA partners, i.e., carrying $5^{\prime}$ triphosphate and $3^{\prime}-\mathrm{OH}$ ends, recombination sites were located at internal positions within the overlapping sequence. In contrast, when using a $5^{\prime}$ partner with a $3^{\prime}-\mathrm{P}$ or a $3^{\prime}$ partner with a $5^{\prime}-\mathrm{OH}$, the activated fragment was entirely incorporated into the genome in most recombinants [173].

Subsequently, the generation of infectious recombinant genomes in the absence of functional RdRp was also demonstrated in Bovine viral diarrhea virus (BVDV) and Hepatitis C virus (HCV), from the Flaviviridae family, while using similar co-transfection systems with defective RNA partners, which suggests that the mechanism of nonreplicative recombination could be common to several positive-strand RNA viruses [174-177]. Whereas the replicative copy-choice model is widely admitted in all RNA viruses, there is now evidence that recombinant RNA genomes can also be produced through a fundamentally different nonreplicative mechanism. This mechanism could represent an alternative or parallel pathway to replicative recombination in vivo, at least in some positive-strand RNA viruses, including EVs.

\subsubsection{Putative Implication of Cellular Factors}

The details of the mechanism(s) that lead to the generation of recombinant genomes in the absence of viral RdRp still remain unknown. The studies previously mentioned, performed in PV, BVDV, and $\mathrm{HCV}$, suggested the existence of a common mechanism of breakage-ligation, very likely involving cellular factors [124,173,175-177]. Recombining RNA fragments could be generated by sporadic bond dissociation or, more probably, by cellular exo- and endoribonucleases, as suggested by the fact that recombination preferentially occurred in single-stranded regions and was promoted by fragments carrying $3^{\prime}-\mathrm{P}$ and $5^{\prime}-\mathrm{OH}$ ends $[173,175]$. Such RNA fragments can actually be produced in vivo, in particular by endoribonucleolytic cleavages [178]. These activated 3 '-P and 5'-OH fragments would then be rejoined by cellular ligases or through self-ligation [28]. Indeed, human cell extracts have been shown to be able to ligate 3'-P-terminated RNA substrates, probably through a preliminary modification by a cyclase [179]. A positive linear correlation between RNA concentration and recombination frequency was actually observed in BVDV and HCV, as would be predicted by a random breakage-ligation mechanism $[175,176]$. Thus, the nonreplicative RNA recombination mechanism might resemble the process of enzymatic splicing leading to the production of mature tRNA in vertebrates [179]. Nevertheless, the cellular factors that are implicated in nonreplicative recombination have not been identified yet.

\subsubsection{Alternative Mechanisms of RNA Recombination not Involving Viral RNA-Dependent RNA Polymerase}

Other mechanisms of RNA recombination have been proposed to explain the recovery of complete viral genomes from defective RNA fragments in the absence of viral RdRp. In particular, it was demonstrated that the RNA molecules are able to undergo spontaneous nonenzymatic intermolecular transesterification reactions [180-183]. This ability is linked to the predisposition of RNA to self-assembly, which enables it to form multi-motif functional complexes (ribozymes) where consecutive cleavage-ligation reactions can be performed. This innate capacity for nonenzymatic recombination is thought to have contributed to the development of the RNA world. This mechanism could be implicated, in particular, in the generation of recombination products containing a recombination site located within RNA secondary structures, such as pseudo-knots, bulges or loops [124]. 
In addition, the fact that RNA recombination can occur in the absence of a functional RdRp does not completely exclude a replicative mechanism of primer extension that would be mediated by cellular polymerases [174]. So far, cellular RdRps have not been identified in mammals. However, host DNA-dependent RNA polymerases, such as RNA polymerase II, have been reported to replicate and recombine RNA genomes of HDV and plant viroids [184-186]. Even though RNA replication of most RNA viruses, including picornaviruses and flaviviruses, occurs in the cytoplasm and promoter-like elements for cellular polymerases have not been described in the genomes of these viruses, a possible RNA recombination mechanism of primer extension by a host polymerase cannot be fully excluded.

\section{Recent Experimental Systems Designed to Study Recombination in Enteroviruses}

Several recent studies have investigated the intra- and intertypic EV recombination process in experimental settings in order to understand the rules governing genetic exchanges between EVs, that can lead in particular to the emergence of pathogenic recombinant cVDPVs $[77,121,122,187,188]$. In these studies, similar recombination cellular systems were developed mimicking natural genetic exchanges between EVs. These systems were based on the co-transfection experiments previously described and carried out by Gmyl et al. to study nonreplicative recombination in PV $[124,173]$. Their principle relied on the rescue by recombination of a defective EV RNA genome after co-transfecting cells with an infectious or defective complementary EV genomic RNA (Figure 5). According to the EV strains that were chosen to construct the RNA partners, the systems enabled studying intratypic, intertypic, or even interspecies recombination. Depending on the design of the two RNA partners, recombination was targeted to a specific genomic region, either the non-structural region $[121,122,188]$ or the 5' UTR [77], or could occur in the major part of the viral genome [187]. Following co-transfection, viable recombinant viruses were isolated as early as possible to minimize their loss or evolution through continued propagation and competition, and thus to analyze early recombination events in EVs. The genomic sequences of the recombinant viruses were then compared with those of the parental partners, in order to determine the location and structure of the recombination sites [77,121,122,187,188]. 
(a)

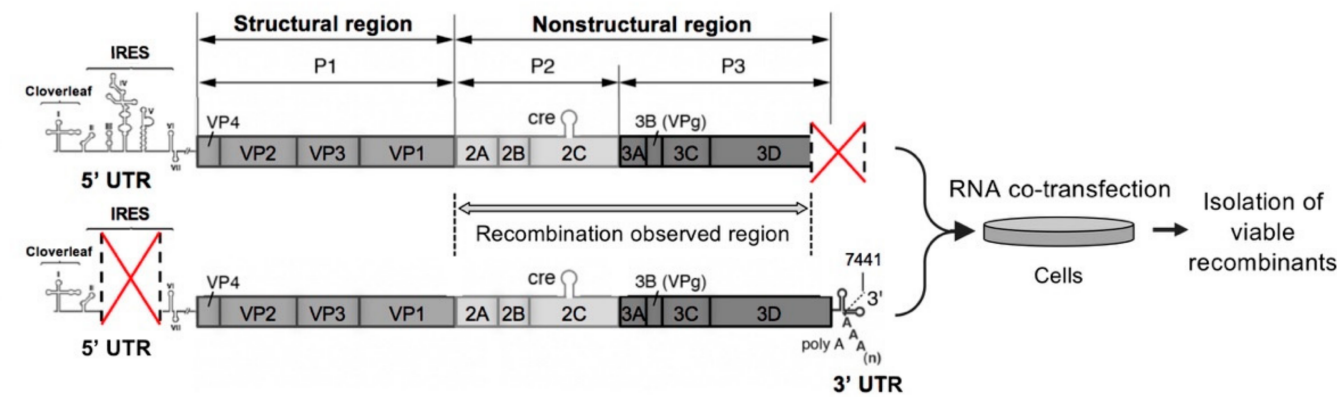

(b)

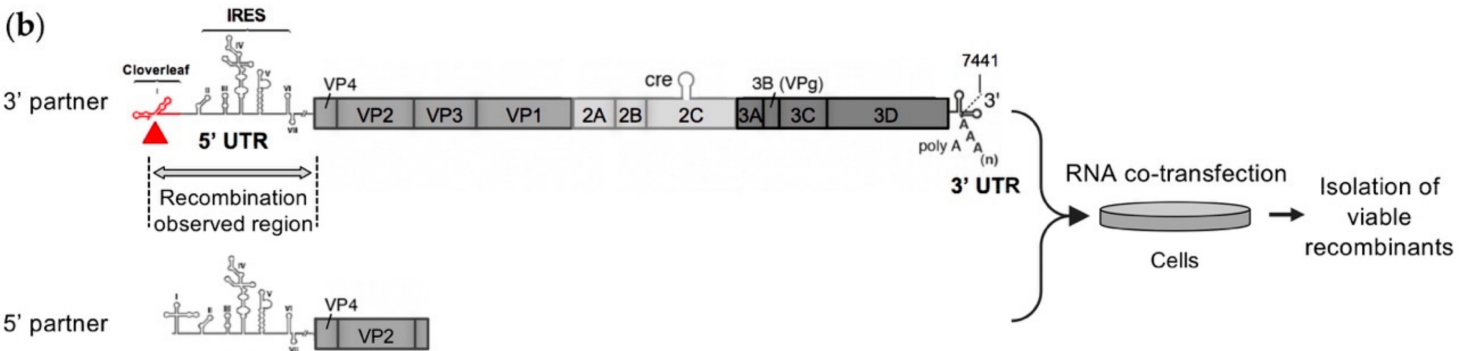

5' UTR

(c)

\begin{tabular}{|c|c|c|c|c|c|c|}
\hline $\begin{array}{l}\text { Target region } \\
\text { for }\end{array}$ & 5' UTR & P2 & \multicolumn{4}{|c|}{ P2-P3 } \\
\hline 3' partners & PV2 (EV-C) & $\begin{array}{l}\text { PV3 (EV-C), } \\
\text { PV1 (EV-C) }\end{array}$ & $\begin{array}{l}\text { CV-A17 (EV-C), } \\
\text { CV-A11 (EV-C), } \\
\text { PV2 (EV-C) }\end{array}$ & RV-A16 (RV-A) & $\begin{array}{l}\text { RV-B14 (RV-B), } \\
\text { RV-C11 (RV-C) }\end{array}$ & $\begin{array}{l}\text { EV-A71 } \\
\text { (EV-A) }\end{array}$ \\
\hline 5 ' partners & $\begin{array}{l}\text { CV-A17 (EV-C), CV-A13 } \\
\text { (EV-C), EV-D70 (EV-D), } \\
\text { CV-B4 (EV-B), E25 (EV-B), } \\
\text { EV-A71 (EV-A) }\end{array}$ & PV3 (EV-C) & PV2 (EV-C) & $\begin{array}{l}\text { RV-A16 (RV-A), RV-A39 } \\
\text { (RV-A), RV-B14 (RV-B), } \\
\text { RV-C11 (RV-C) }\end{array}$ & RV-A16 (RV-A) & $\begin{array}{l}\text { EV-A71 } \\
\text { (EV-A) }\end{array}$ \\
\hline Reference & [77] & [121] & {$[122,189]$} & [187] & & [188] \\
\hline
\end{tabular}

Figure 5. Experimental systems of intra- and intertypic recombination between enteroviruses. (a) and (b). Examples of recombination partners designed to target recombination in the P2-P3 region (a) and in the $5^{\prime}$ UTR (b). (a) The $3^{\prime}$ partner is made from the complete enterovirus genome in which the $3^{\prime}$ end of the 3D polymerase and the entire $3^{\prime}$ UTR were deleted. The $5^{\prime}$ partner is made from the enterovirus genome carrying a deletion in the IRES. Red crosses indicate the genomic regions in which deletions were made. Co-transfecting cells with these two defective complementary genomic RNA fragments led to the production of infectious genomes recombinant in the P2-P3 region [122,189]. (b) The 3' partner is made defective by substitutions in the cloverleaf structure of $5^{\prime}$ UTR. The $5^{\prime}$ partner includes the complete $5^{\prime}$ UTR followed by the N-terminal part of the ppORF. Co-transfecting cells with this pair of defective genomes will generate viable viruses only if a recombination event occurs in the $5^{\prime}$ UTR [77]. (c) List of enterovirus types used for the construction of the $3^{\prime}$ and $5^{\prime}$ partners in the different experimental systems. For each type, the enterovirus species is indicated in brackets.

All of these experimental studies of intra- and intertypic recombination in EVs provided similar results regarding the features of the generated infectious recombinant genomes, in particular the ratio of homologous to nonhomologous recombinants and the location of recombination sites, regardless of the tested RNA partner pair and the genomic region targeted for recombination. No significant differences in the genomic structure of the obtained recombinants were observed whether the defective EV genome was rescued with a replicable or nonreplicable RNA fragment, i.e., whether the initial step in the generation of the recombinants involved a replicative or nonreplicative RNA recombination event $[121,122]$. 


\section{The Generation of Homologous Intertypic Recombinant Enteroviruses, a Multi-Step Process}

Both homologous infectious recombinant genomes and nonhomologous ones, showing deletions or insertions at the recombination site, were recovered from the recombination cellular systems previously described. When both RNA partners belonged to the same type, homologous recombinant genomes were mostly isolated [121,122]. On the contrary, intertypic and interspecies recombination generated mainly nonhomologous recombinants $[77,121,122,187]$. Very few, 0 to $4 \%$, isolated genomes recombinant in the non-structural region showed deletions at the recombination site, and the length of the deleted sequence never exceeded two codons, reflecting the fact that nonhomologous recombination generating deletions of coding sequences is likely to produce non-viable or non-competitive genomes [121,122,187]. However, $33 \%$ of the genomes with a recombination site in the $5^{\prime}$ UTR displayed deletions, up to 164 nucleotides, in particular, when the recombination site was located in the dVII-spacer 2 region, between the IRES and the ppORF initiation codon [77]. These recombinants appeared to be very stable upon successive cellular passages and fitter than some homologous recombinants in the $5^{\prime}$ UTR. These observations are consistent with previous reports that suggested the dVII-spacer 2 region of EVs can tolerate profound modifications without significant phenotypic changes [190,191]. Indeed, one of the 12 natural recombinant type $2 \mathrm{cVDPV}$ lineages with non-PV EV $5^{\prime}$ UTR sequences that have been described so far showed a shorter spacer suggesting that a deletion occurred during recombination [70-73].

Most of the isolated nonhomologous recombinant genomes displayed inserted sequences of a variable number of additional nucleotides, which usually created duplications of homologous parental sequences on each site of the recombination site, and could reach a length of around 570 nucleotides in the 5' UTR [77] and 148 codons in the non-structural region [187]. However, none of the natural recombinant EVs reported to date, including cVDPVs, exhibit clear signs of genomic duplications. Studies of some of the nonhomologous recombinants with insertions that were obtained with the recombination cellular systems previously described showed that they had growth and fitness disadvantages as compared to parental and homologous recombinant strains $[77,121]$. These nonhomologous recombinants would then only be present transiently in infected cells and organisms. Analyses of the in vitro and in vivo evolution of the duplicated sequences that were located in the non-structural region or in the $5^{\prime}$ UTR showed that they were frequently progressively deleted by genomic rearrangement following passaging in cells or animals, resulting in homologous recombinants $[77,121,122]$. These genomic rearrangement events are likely replicative, given that a functional polymerase is available to the virus. Indeed, it has been shown, in various positive-strand RNA viruses, that copy-choice recombination is capable of precisely removing genomic duplications with high efficiency $[35,163,192,193]$. Moreover, genomic rearrangement events are thought to be largely responsible for the formation of defective interfering particles (DIs), which are truncated forms of viral genomes that accumulate during replication of RNA viruses $[126,194,195]$. A Sindbis virus artificially modified in its polymerase was found to overproduce DIs, supporting the hypothesis of the implication of a replicative recombination mechanism [194]. As mentioned earlier in this review, the frequency of replicative recombination is positively correlated to the percentage of sequence identity between the two parental sequences $[79,121,149,164,165,196,197]$. Consistent with these reports, genomic rearrangements were found to occur faster when the sequence identity that was shared by the parental duplicated sequences increased [77]. Thus, first-generation nonhomologous intertypic recombinants undergo maturation through one or more subsequent genomic rearrangement events, which lead to the emergence of fitter homologous recombinants. A single nonhomologous recombinant was shown to be able to generate several different homologous recombinant genomes [121,122]. Nonhomologous recombinants could then be considered as precursors of the diversity of homologous recombinants genomes (Figure 6). In the case of intratypic recombination, the homologous recombinant genomes, which accounted for the majority of the isolated recombinants, might have been generated through a single precise recombination event, or may be the result of a faster evolution of nonhomologous recombinants promoted by the sequence identity level between the parental duplicated sequences. 

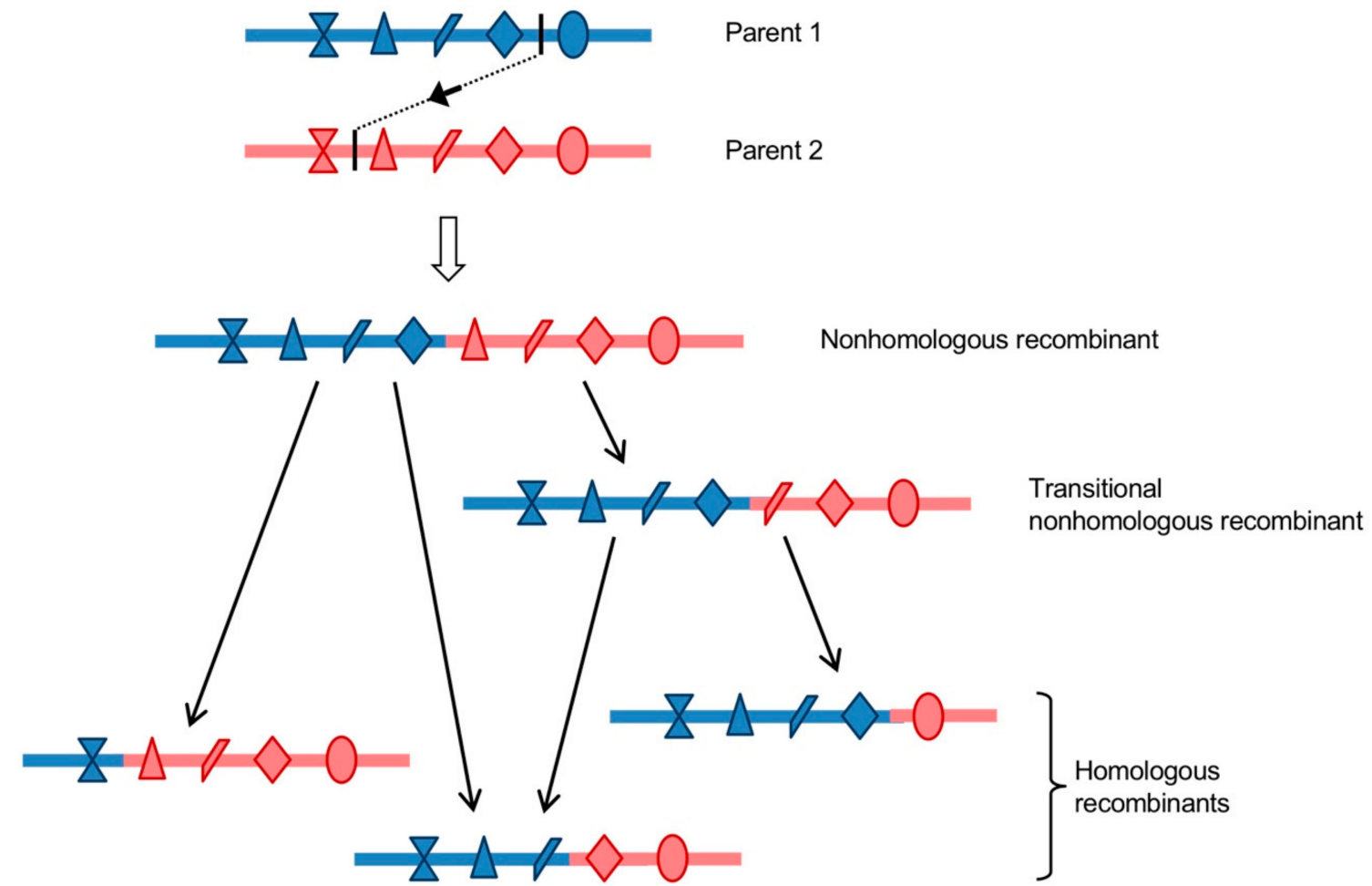

Figure 6. Model of generation of homologous recombinants from a nonhomologous one. A nonhomologous recombinant genome, displaying a duplication of homologous sequences around the recombination site, is produced by a replicative or nonreplicative recombination mechanism. Icons represent differences between the two homologous parental genomes. During the following replication cycles, the nonhomologous recombinant genome can generate a series of homologous recombinants through one or more rearrangement event(s). Recombination and rearrangement may take place within the initial co-infected (or co-transfected) cell, or in a different cell following re-infection, supposing that the nonhomologous recombinant can be encapsidated [189].

To conclude, these recent experimental studies of recombination in EVs led to the elaboration of a new model for the generation of homologous recombinant EV genomes. Homologous recombinant EVs that are observed in nature could have directly arisen through replicative homologous recombination, according to the previously proposed copy-choice model, or as the result of successive nonhomologous recombination events. In the latter scenario, initial nonhomologous recombinants, which could have been generated by either replicative or nonreplicative recombination, would then evolve into homologous recombinants over one or more subsequent replicative recombination events. Nonhomologous recombinant genomes would function as precursors and recombination intermediates in a multi-step process that leads to the emergence of a diversity of homologous recombinants (Figure 6). This model could be generalized to other positive-strand RNA viruses, as suggested for HCV [28].

\section{Recombination in Enteroviruses, Experimental Evidences of a Modular Evolutionary Process}

\subsection{Location of Recombination Hotspots}

Another common feature of the viable recombinant genomes that were isolated from the recombination cellular systems is that recombination sites appeared not to be randomly distributed within the targeted genomic region, instead being located in recombination "hotspot" regions. Experimental studies of intertypic RNA recombination between PV and EV genomes enabled defining six recombination hotspots throughout the EV genome: three in the 5' UTR and three in the non-structural region [77,121,122]. The distribution of recombination sites seemed to depend on the type of recombinant. Nonhomologous recombination sites were exclusively found in the hotspot 
sequences, whereas homologous recombination sites could also be found elsewhere in the targeted region. The recombination cellular systems were designed to analyze early but viable products of recombination. Thus, the features of the isolated recombinant genomes, including the recombination sites location, were the result of combined mechanistic and viability constraints. Importantly, a first study by deep sequencing of both viable and defective homologous recombinants produced by intratypic recombination in PV type 1 (PV1) identified recombination sites located all along the genome [153]. These results suggest that the recombination hotspots previously described might correspond to regions where recombination is more likely to produce viable genomes rather than sequences where recombination is mechanically favored, even though this last hypothesis cannot be fully excluded.

Figure 7a presents the location of the six recombination hotspots. Three recombination hotspots were identified in the 5' UTR: spacer 1 between the CL and the IRES, the linker sequence between IRES domains $\mathrm{dV}$ and $\mathrm{dVI}$, and the dVII-spacer 2 region linking the IRES to the ppORF [77]. Three other recombination hotspots were identified in the non-structural region, each one being predominantly constituted by nonhomologous recombination sites and located at the junction between two viral genes: VP1-2A, 2A-2B, and 2C-3A [121,122]. Interestingly, the existence and location of these recombination hotspots appeared not to depend on the parental strains used as RNA partners, and may thus be considered as a general feature of RNA recombination between PV and EV genomes. However, it is important to emphasize that these recombination hotspots were identified in EV genomes that were produced in artificial recombination cellular systems, where environmental conditions and constraints are obviously very different from those of an in vivo infection. Yet, interestingly, the recombination hotspots identified in the in vitro selected recombinants correlated quite well with those of the natural cVDPVs lineages described so far. Indeed, among the 26 genomes of natural cVDPV lineages described to date, which were recombinant between OPV and non-PV EV-C sequences, 17 displayed a recombination site that was located in one of the three hotspots experimentally identified in the non-structural region (Figure 3). Eight recombination sites were located in the VP1-2A hotspot, seven in the 2A-2B hotspot, and two in the 2C-3A hotspot [65-73]. The nine other cVDPV lineages had recombination sites that were located in other sites of the nonstructural region, in particular in the $2 \mathrm{C}$ gene. Moreover, five of the cVDPVs displayed a second recombination site in the non-structural region, at the end of the $3 \mathrm{C}$ or $3 \mathrm{D}$ genes. In addition, among the 12 natural recombinant type $2 \mathrm{cVDPV}$ lineages with non-PV EV 5' UTR sequences, ten showed recombination sites in the dVII-spacer 2 region and two in the linker sequence between domains dV and dVI (Figure 3) [70-73]. Recombination in spacer 1 has not been described so far in natural cVDPVs. 
(a)

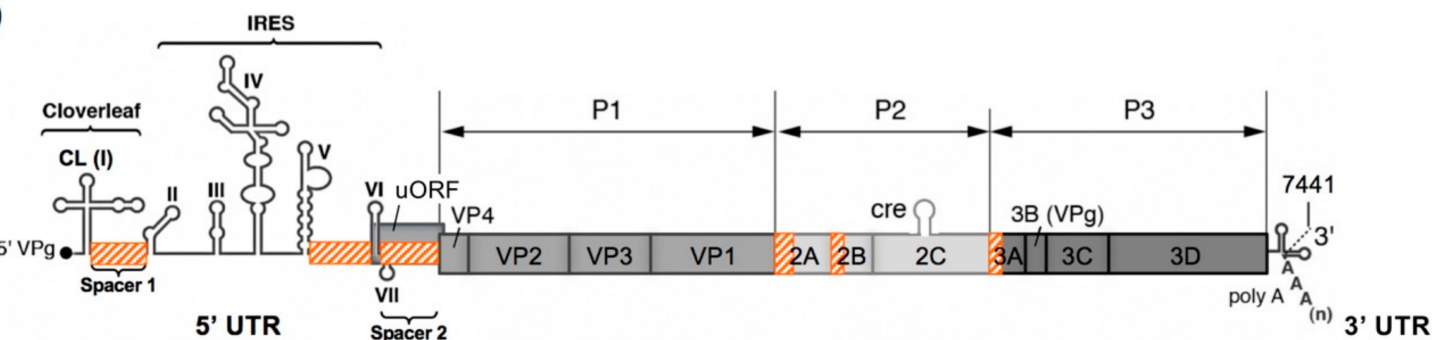

(b)

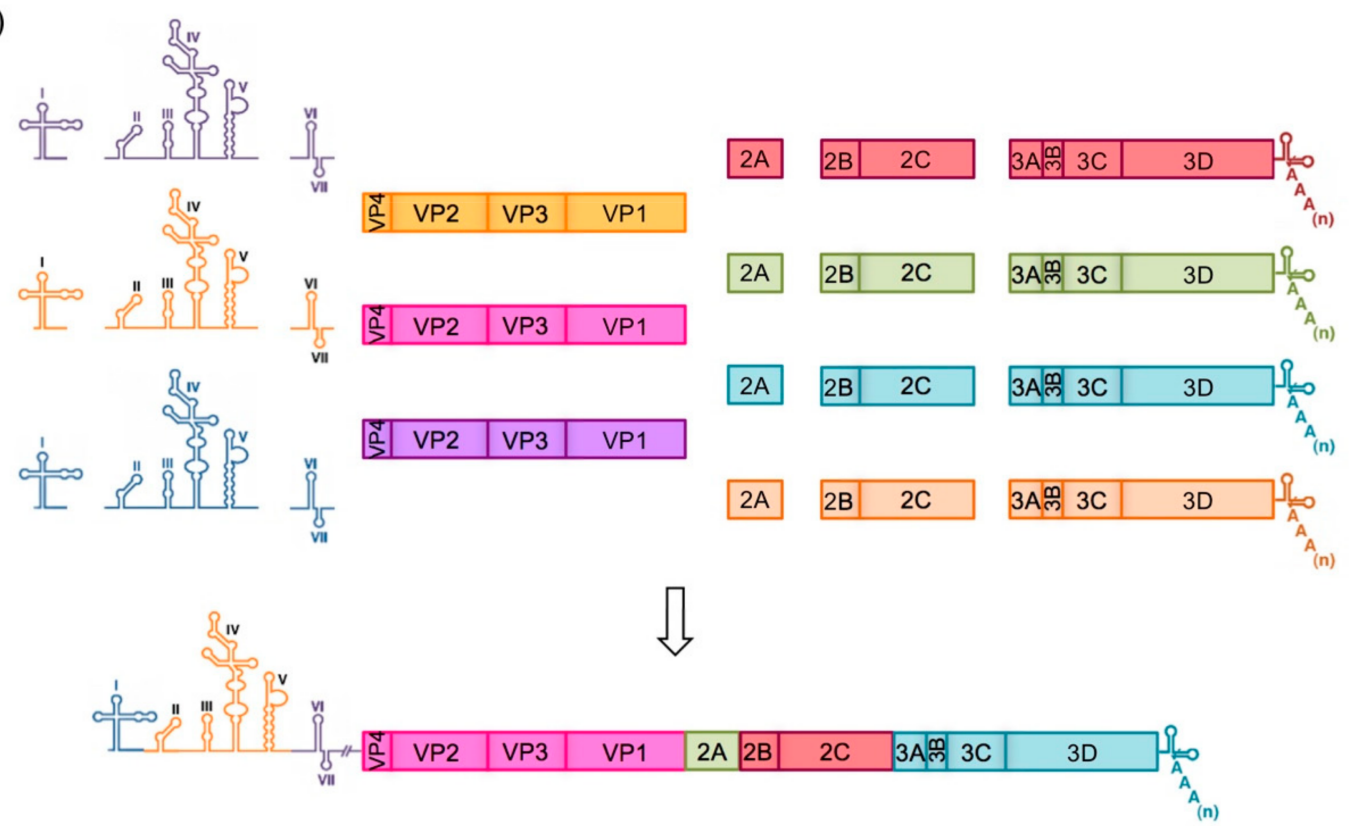

Figure 7. Model of modular evolution of species $C$ enteroviruses. (a) Schematic representation of the enterovirus genomic RNA molecule. Experimental studies of genetic exchanges between poliovirus and enteroviruses led to the identification of six putative intertypic recombination hotspots, indicated by hatched orange rectangles [77,121,122]. (b) Modular recombination process. Each enterovirus species would exist as a pool of genetic material containing a finite set of P1 regions defining different types and a swarm of nonstructural and untranslated regions, divided in functional recombination modules and evolving independently. Each new enterovirus lineage can be considered as a new association of compatible recombination module.

Given that the recombinants that were isolated from the in vitro recombination systems were viable viruses replicating in cultured cells, it was also interesting to investigate their ability to replicate in vivo and their pathogenicity following the inoculation of transgenic homozygous PVR-Tg21 mice, which constitutively express the human PV cellular receptor CD155 [198,199]. In the case of recombination in the $5^{\prime}$ UTR between an EV 5' partner from 5' UTR group I (EV-C or EV-D) and a PV2 $3^{\prime}$ partner, homologous recombinants with recombination sites located at the three identified hotspots appeared to be as neurovirulent as the PV2 partner [77]. Homologous as well as nonhomologous recombinant viruses between a PV2 $5^{\prime}$ partner and a CV-A17 $3^{\prime}$ partner with recombination sites located in VP1-2A or $2 \mathrm{~A}-2 \mathrm{~B}$ hotspots were also found to replicate and be pathogenic in mice $[76,122]$.

\subsection{Modular Recombination Process}

The existence of recombination hotspots in the 5' UTR and the region encoding nonstructural EV proteins was demonstrated in intertypic recombinants that were obtained from recombination cellular systems $[77,121,122]$. These recombination hotspots flank genomic sequences with very low rates of 
recombination, thus defining "recombination modules". As previously mentioned, the hotspot location, and so the recombination module boundaries, likely result from the selection forces acting on and preserving viral functions. The modules could then be considered as functional recombination modules. The 5' UTR and the non-structural region of EVs appeared to be composed of three recombination modules each: the non-coding regions of the $\mathrm{CL}$, of the IRES domains $\mathrm{dII}$ to $\mathrm{dV}$ and of the domain $\mathrm{dVI}$, and the regions encoding viral proteins $2 \mathrm{~A}, 2 \mathrm{BC}$, and $3 \mathrm{ABCD}$ (Figure 7). These genomic recombination modules are exchanged through RNA recombination occurring at the defined hotspots. Thus, intertypic EV recombination appeared to be a modular process, during which successive recombination events involving hotspots would lead to the construction of mosaic EV genomes.

In conclusion, the different recent studies that are presented in this review, which investigated the genetic exchanges between a panel of EV genomes in cellular systems, enabled experimentally demonstrating the theoretical model of EV evolution through modular recombination that had been proposed from phylogenetic studies of EV strains (see §2.4). These studies provided experimental evidence supporting phylogenetic data that EV genomes should be considered as combinations of genomic fragments, or recombination modules. These recombination modules would evolve independently and combine through RNA recombination during co-infections. The possible combinations of recombination modules generating viable EV genomes could be determined by preferred mutual functional compatibility, which was shown to be strikingly conserved between co-circulating EVs of the same species [78,97]. A recent study of the patterns of intertypic recombination of Sabin PVs demonstrated that the intrinsically higher/lower relative fitness of the recombination modules also played a significant role in their acquisition/loss by recombination [117]. Furthermore, these experimental studies enabled defining the boundaries of the recombination modules, at least in the context of in vitro PV/PV and PV/non-PV recombination. Some of the recombination modules that were identified correlated with known functional units, like the $\mathrm{CL}$, the IRES and uORF in the $5^{\prime}$ UTR, and the $2 \mathrm{~A}$ and $2 \mathrm{BC}$ proteins in the non-structural region.

\section{Concluding Remarks}

Despite the importance of RNA recombination in the evolution of EVs [61,106,111], as well as other important positive-strand RNA virus pathogens [91,200,201], the underlying mechanism(s) by which recombinants arise remains relatively poorly understood. Recent experimental studies that relied on recombination cellular systems mimicking natural genetic exchanges between EVs provided new insights into the molecular mechanisms of recombination in EVs, and enabled defining a new model of EV evolution through recombination $[77,121,122,187,188]$. The obtained data suggest that homologous intertypic recombinant EVs observed in nature are the final products of a multi-step process during which precursor nonhomologous recombinant genomes are generated through an initial inter-genomic recombination event and can then create a diversity of homologous recombinant genomes over one or more subsequent genomic rearrangement(s). Two main nonexclusive mechanisms of RNA recombination exist in EVs: a replicative copy-choice mechanism and a nonreplicative breakage-ligation mechanism. However, their relative contribution to the composition of the recombinant swarm remains unclear. In the recombination cellular systems that are reviewed here, co-transfecting cells either with two defective RNA partners or with a defective and a replicable RNA partners produced viable recombinant progenies with similar genomic features, which suggests a common intertypic RNA recombination process. This process would involve a first recombination step either replicative or nonreplicative, mostly producing nonhomologous recombinant genomes, followed by rapid evolution through replicative recombination, leading to the excision of the duplicated regions. Nonreplicative recombination and nonhomologous recombinant production seem to be favored in these recombination cellular systems in which RNA partners are nonreplicable and cells are co-transfected with great amounts of RNA molecules, which likely activates cellular RNA degradation pathways that are supposed to be involved in the nonreplicative breakage-ligation mechanism. Thus, it remains 
to determine whether this mechanism is still relevant in the context of natural infection and the recombination of functional genomes.

Moreover, these experimental studies highlighted a novel aspect of the organization of the EV genome. The genome of EVs could be defined as a combination of genomic modules that can be exchanged through RNA recombination. These results provided the first experimental evidence that supported the theoretical model of EV modular evolution previously elaborated from phylogenetic studies [106,111]. The recombination module boundaries were experimentally defined in the context of intertypic PV/PV and PV/non-PV recombination, which is implicated in the emergence of cVDPVs [77,121,122]. A good correlation was observed between the recombination hotspots that were experimentally located and the features of the natural cVDPV genomes described to date, validating the relevance of these recombination cellular systems mimicking natural genetic exchanges between EVs. It is important to note that this modular process might not apply to intratypic recombination, or that the location of the functional recombination module boundaries may be different, given that the structural and functional compatibility of recombining sequences is much higher in the context of intratypic recombination. In addition, as most of the results supporting the concept of modular evolution were obtained from recombination experiments that involved $\mathrm{PV}$, it requires further investigation in non-PV EVs. It remains, in particular, to determine whether the location of the intertypic recombination hotspots could be generalized to all the EVs. A recent large-scale analysis of intertypic recombination patterns in human EV-A, EV-B, and EV-C genomes detected two of the three recombination hotspots that were experimentally identified in the $5^{\prime}$ UTR: the linker sequence between IRES domains $\mathrm{dV}$ and $\mathrm{dVI}$, the latter containing the initiation codon of the $\mathrm{uORF}$, and the dVII-spacer 2 region linking the IRES to the ppORF $[77,108]$. It is worth noting that the dVII-spacer 2 region, which was found to be the most prominent recombination hotspot in both experimental and phylogenetic studies, is located within the uORF harbored by the majority of EV-A and EV-B genomes and around half the EV-C genomes, which suggests a high tolerance of the single uORF protein to sequence alterations. Regarding the non-structural region, Nikolaidis et al. identified the P2 region, and, in particular, the 2A gene, as a preferential recombination region in circulating EV-B and EV-C genomes [108]. This observation is compatible with the existence of recombination hotspots that are located at VP1-2A and $2 \mathrm{~A}-2 \mathrm{~B}$ junctions that would lead to the generation of nonhomologous recombinant genomes further evolving into homologous recombinants with recombination sites in the $2 \mathrm{~A}$ gene, as postulated by the proposed multi-step modular recombination model. In addition, the location of these two experimentally identified recombination hotspots is consistent with the high flexibility of EV 2A protein previously reported [202,203]. However, while the experimental systems of PV/EV-C recombination in the non-structural region enabled detecting only one additional intertypic recombination hotspot, at the 2C-3A junction (Figure 7), phylogenetic studies on circulating human EV genomes reported a more even distribution of recombination sites across the whole P2 and P3 regions [86,108-111]. One hypothesis that might explain this discrepancy is that the location of the non-structural recombination hotspots, and so the boundaries of the recombination modules constituting the EV non-structural region, is type- or genogroup-specific. Type-specific recombination modules were indeed recently identified in the non-structural region of Sabin 1, 2, and 3 PV genomes [117]. Furthermore, the recombination module boundaries could also depend on the nature of both recombination partners, as some asymmetries in reciprocal recombination were reported [74], and that certain species are thought to be more tolerant to recombination than others [108,111].

The structural and functional constraints that limit the exchanges of functional recombination modules also require further evaluation. For instance, recombination within the coding regions of human EV genomes has been thought to only occur among members of a given species [111]. However, interspecies recombination events in the non-structural region of the genome were found to have led to the emergence of non-human primate EV isolates within the EV-A and EV-B species [204]. Furthermore, genomes of porcine EV strains from the EV-G species were recently shown to have acquired a functional gene sequence from a Torovirus, member of the Coronaviridae family, by recombination at the VP1-2A 
junction $[45,46]$. These data suggest that the EV genome plasticity might be even higher than previously thought, at least in certain EVs infecting non-human animals.

Finally, the concept of genome evolution through exchanges of recombination modules might apply to other RNA virus families. Indeed, similar recombination models have been suggested for viruses from the Flaviviridae family [205], for coronaviruses [206] and BMV [207]. At a larger scale, the study of the macroevolution of invertebrate RNA viruses revealed patterns of modular genome evolution through widespread recombination among structural and non-structural genomic regions, which leads to the acquisition, removal, and exchanges of functional units over long evolutionary timescales [208]. Thus, to a different extent, modular genome evolution might be considered to be a common feature of RNA viruses.

Funding: This work was supported by the Institut Pasteur, the Universidad de las Américas, a "Programme Transversal de Recherche PTR484" grant, and a TOTAL Foundation grant (https://www.foundation.total/fr).

Conflicts of Interest: The authors declare no conflict of interest.

\section{References}

1. Zell, R.; Delwart, E.; Gorbalenya, A.E.; Hovi, T.; King, A.M.Q.; Knowles, N.J.; Lindberg, A.M.; Pallansch, M.A.; Palmenberg, A.C.; Reuter, G.; et al. ICTV Virus Taxonomy Profile: Picornaviridae. J. Gen. Virol. 2017, 98, 2421-2422. [CrossRef] [PubMed]

2. Pallansch, M.; Roos, R. Enteroviruses: Polioviruses, coxsackieviruses, echoviruses, and newer enteroviruses. In Fields Virology; Knipe, D.M., Howley, P.M., Eds.; Lippincott Williams and Wilkins: Philadelphia, PA, USA, 2007; pp. 839-893.

3. Nathanson, N.; Kew, O.M. From emergence to eradication: The epidemiology of poliomyelitis deconstructed. Am. J. Epidemiol. 2010, 172, 1213-1229. [CrossRef] [PubMed]

4. Rao, C.D.; Yergolkar, P.; Shankarappa, K.S. Antigenic diversity of enteroviruses associated with nonpolio acute flaccid paralysis, India, 2007-2009. Emerg. Infect. Dis. 2012, 18, 1833-1840. [CrossRef] [PubMed]

5. Yang, T.-T.; Huang, L.-M.; Lu, C.-Y.; Kao, C.-L.; Lee, W.-T.; Lee, P.-I.; Chen, C.-M.; Huang, F.-Y.; Lee, C.-Y.; Chang, L.-Y. Clinical features and factors of unfavorable outcomes for non-polio enterovirus infection of the central nervous system in northern Taiwan, 1994-2003. J. Microbiol. Immunol. Infect. 2005, 38, 417-424. [PubMed]

6. Rudolph, H.; Schroten, H.; Tenenbaum, T. Enterovirus Infections of the Central Nervous System in Children: An Update. Pediatr. Infect. Dis. J. 2016, 35, 567-569. [CrossRef] [PubMed]

7. Tracy, S.; Chapman, N.M. Group B coxsackievirus disease. In The Picornaviruses; Ehrenfeld, E., Domingo, E., Roos, R.P., Eds.; ASM Press: Washington, DC, USA, 2010; pp. 353-368.

8. Muehlenbachs, A.; Bhatnagar, J.; Zaki, S.R. Tissue tropism, pathology and pathogenesis of enterovirus infection. J. Pathol. 2015, 235, 217-228. [CrossRef] [PubMed]

9. Pons-Salort, M.; Parker, E.P.K.; Grassly, N.C. The epidemiology of non-polio enteroviruses: Recent advances and outstanding questions. Curr. Opin. Infect. Dis. 2015, 28, 479-487. [CrossRef] [PubMed]

10. Tapparel, C.; Siegrist, F.; Petty, T.J.; Kaiser, L. Picornavirus and enterovirus diversity with associated human diseases. Infect. Genet. Evol. 2013, 14, 282-293. [CrossRef]

11. Jacques, J.; Moret, H.; Minette, D.; Lévêque, N.; Jovenin, N.; Deslée, G.; Lebargy, F.; Motte, J.; Andréoletti, L. Epidemiological, molecular, and clinical features of enterovirus respiratory infections in French children between 1999 and 2005. J. Clin. Microbiol. 2008, 46, 206-213. [CrossRef]

12. Racaniello, V.R. Picornaviridae: The viruses and their replication. In Fields Virology; Knipe, D.M., Howley, P.M., Eds.; Lippincott Williams and Wilkins: Philadelphia, PA, USA, 2007; pp. 795-838.

13. Lulla, V.; Dinan, A.M.; Hosmillo, M.; Chaudhry, Y.; Sherry, L.; Irigoyen, N.; Nayak, K.M.; Stonehouse, N.J.; Zilbauer, M.; Goodfellow, I.; et al. An upstream protein-coding region in enteroviruses modulates virus infection in gut epithelial cells. Nat. Microbiol. 2018, 4, 280.

14. Andino, R.; Rieckhof, G.E.; Baltimore, D. A functional ribonucleoprotein complex forms around the $5^{\prime}$ end of poliovirus RNA. Cell 1990, 63, 369-380. [CrossRef]

15. Barton, D.J.; O'Donnell, B.J.; Flanegan, J.B. 5' cloverleaf in poliovirus RNA is a cis-acting replication element required for negative-strand synthesis. EMBO J. 2001, 20, 1439-1448. [CrossRef] [PubMed] 
16. Rieder, E.; Xiang, W.; Paul, A.; Wimmer, E. Analysis of the cloverleaf element in a human rhinovirus type 14/poliovirus chimera: Correlation of subdomain D structure, ternary protein complex formation and virus replication. J. Gen. Virol. 2003, 84, 2203-2216. [CrossRef] [PubMed]

17. Vogt, D.A.; Andino, R. An RNA element at the $5^{\prime}$-end of the poliovirus genome functions as a general promoter for RNA synthesis. PLoS Pathog. 2010, 6, 1000936. [CrossRef]

18. Nicholson, R.; Pelletier, J.; Le, S.Y.; Sonenberg, N. Structural and functional analysis of the ribosome landing pad of poliovirus type 2: In Vivo translation studies. J. Virol. 1991, 65, 5886-5894.

19. Sweeney, T.R.; Abaeva, I.S.; Pestova, T.V.; Hellen, C.U.T. The mechanism of translation initiation on type 1 picornavirus IRESs. EMBO J. 2014, 33, 76-92. [CrossRef]

20. Wimmer, E.; Paul, A. The making of a Picornavirus genome. In The Picornaviruses; Ehrenfeld, E., Domingo, E., Roos, R.P., Eds.; ASM Press: Washington, DC, USA, 2010; pp. 33-55.

21. Mueller, S.; Wimmer, E.; Cello, J. Poliovirus and poliomyelitis: A tale of guts, brains, and an accidental event. Virus Res. 2005, 111, 175-193. [CrossRef]

22. Domingo, E.; Sheldon, J.; Perales, C. Viral Quasispecies Evolution. Microbiol. Mol. Biol. Rev. 2012, 76, $159-216$. [CrossRef]

23. Lauring, A.S.; Andino, R. Quasispecies theory and the behavior of RNA viruses. PLoS Pathog. 2010, 6, 1-8. [CrossRef]

24. Pfeiffer, J.K.; Kirkegaard, K. Increased fidelity reduces poliovirus fitness and virulence under selective pressure in mice. PLoS Pathog. 2005, 1, 0102-0110. [CrossRef]

25. Gnädig, N.F.; Beaucourt, S.; Campagnola, G.; Bordería, A.V.; Sanz-Ramos, M.; Gong, P.; Blanc, H.; Peersen, O.B.; Vignuzzi, M. Coxsackievirus B3 mutator strains are attenuated in vivo. Proc. Natl. Acad. Sci. USA 2012, 109, E2294-E2303. [CrossRef] [PubMed]

26. Meng, T.; Kwang, J. Attenuation of Human Enterovirus 71 High-Replication-Fidelity Variants in AG129 Mice. J. Virol. 2014, 88, 5803-5815. [CrossRef] [PubMed]

27. Vignuzzi, M.; Stone, J.K.; Arnold, J.J.; Cameron, C.E.; Andino, R. Quasispecies diversity determines pathogenesis through cooperative interactions in a viral population. Nature 2006, 439, 344-348. [CrossRef] [PubMed]

28. Galli, A.; Bukh, J. Comparative analysis of the molecular mechanisms of recombination in hepatitis $C$ virus. Trends Microbiol. 2014, 22, 354-364. [CrossRef] [PubMed]

29. Pérez-Losada, M.; Arenas, M.; Galán, J.C.; Palero, F.; González-Candelas, F. Recombination in viruses: Mechanisms, methods of study, and evolutionary consequences. Infect. Genet. Evol. 2015, 30, $296-307$. [CrossRef] [PubMed]

30. Sztuba-Solińska, J.; Urbanowicz, A.; Figlerowicz, M.; Bujarski, J.J. RNA-RNA Recombination in Plant Virus Replication and Evolution. Annu. Rev. Phytopathol. 2011, 49, 415-443. [CrossRef] [PubMed]

31. Simon-Loriere, E.; Rossolillo, P.; Negroni, M. RNA structures, genomic organization and selection of recombinant HIV. RNA Biol. 2011, 8, 37-41. [CrossRef]

32. Barr, J.N.; Fearns, R. How RNA viruses maintain their genome integrity. J. Gen. Virol. 2010, 91, $1373-1387$. [CrossRef]

33. Rawson, J.M.O.; Nikolaitchik, O.A.; Keele, B.F.; Pathak, V.K.; Hu, W.-S. Recombination is required for efficient HIV-1 replication and the maintenance of viral genome integrity. Nucleic Acids Res. 2018, 46, 10535-10545. [CrossRef]

34. Kempf, B.J.; Watkins, C.L.; Peersen, O.B.; Barton, D.J. Picornavirus RNA Recombination Counteracts Error Catastrophe. J. Virol. 2019, 93, 652. [CrossRef]

35. Xiao, Y.; Rouzine, I.M.; Bianco, S.; Acevedo, A.; Goldstein, E.F.; Farkov, M.; Brodsky, L.; Andino, R. RNA recombination enhances adaptability and is required for virus spread and virulence. Cell Host Microbe 2016, 19, 493-503. [CrossRef] [PubMed]

36. Xiao, Y.; Dolan, P.T.; Goldstein, E.F.; Li, M.; Farkov, M.; Brodsky, L.; Andino, R. Poliovirus intrahost evolution is required to overcome tissue-specific innate immune responses. Nat. Commun. 2017, 8, 375. [CrossRef] [PubMed]

37. Hahn, C.S.; Lustig, S.; Strauss, E.G.; Strauss, J.H. Western equine encephalitis virus is a recombinant virus. Proc. Natl. Acad. Sci. USA 1988, 85, 5997-6001. [CrossRef] [PubMed] 
38. Weaver, S.C.; Kang, W.; Shirako, Y.; Rumenapf, T.; Strauss, E.G.; Strauss, J.H. Recombinational history and molecular evolution of western equine encephalomyelitis complex alphaviruses. J. Virol. 1997, 71, 613-623. [PubMed]

39. Simmonds, P.; Midgley, S. Recombination in the genesis and evolution of hepatitis B virus genotypes. J. Virol. 2005, 79, 15467-15476. [CrossRef] [PubMed]

40. Charrel, R.N.; de Lamballerie, X.; Emonet, S. Phylogeny of the genus Arenavirus. Curr. Opin. Microbiol. 2008, 11, 362-368. [CrossRef] [PubMed]

41. Jackwood, M.W.; Boynton, T.O.; Hilt, D.A.; McKinley, E.T.; Kissinger, J.C.; Paterson, A.H.; Robertson, J.; Lemke, C.; McCall, A.W.; Williams, S.M.; et al. Emergence of a group 3 coronavirus through recombination. Virology 2010, 398, 98-108. [CrossRef] [PubMed]

42. Marais, A.; Faure, C.; Mustafayev, E.; Candresse, T. Characterization of new isolates of Apricot vein clearing-associated virus and of a new prunus-infecting virus: Evidence for recombination as a driving force in Betaflexiviridae evolution. PLoS ONE 2015, 10, 1-15. [CrossRef]

43. Kelly, A.G.; Netzler, N.E.; White, P.A. Ancient recombination events and the origins of hepatitis E virus. BMC Evol. Biol. 2016, 16, 1-18. [CrossRef]

44. Miras, M.; Sempere, R.N.; Kraft, J.J.; Miller, W.A.; Aranda, M.A.; Truniger, V. Interfamilial recombination between viruses led to acquisition of a novel translation-enhancing RNA element that allows resistance breaking. New Phytol. 2014, 202, 233-246. [CrossRef]

45. Shang, P.; Misra, S.; Hause, B.; Fang, Y. A naturally occurring recombinant enterovirus expresses a torovirus deubiquitinase. J. Virol. 2017, 91, JVI.00450-17. [CrossRef] [PubMed]

46. Tsuchiaka, S.; Naoi, Y.; Imai, R.; Masuda, T.; Ito, M.; Akagami, M.; Ouchi, Y.; Ishii, K.; Sakaguchi, S.; Omatsu, T.; et al. Genetic diversity and recombination of enterovirus $\mathrm{G}$ strains in Japanese pigs: High prevalence of strains carrying a papain-like cysteine protease sequence in the enterovirus G population. PLoS ONE 2018, 13, 1-18. [CrossRef] [PubMed]

47. Gibbs, M.J.; Weiller, G.F. Evidence that a plant virus switched hosts to infect a vertebrate and then recombined with a vertebrate-infecting virus. Proc. Natl. Acad. Sci. USA 1999, 96, 8022-8027. [CrossRef] [PubMed]

48. Alamgir, A.S.M.; Owens, N.; Lavignon, M.; Malik, F.; Evans, L.H. Precise identification of endogenous proviruses of NFS/N mice participating in recombination with moloney ecotropic murine leukemia virus (MuLV) to generate polytropic MuLVs. J. Virol. 2005, 79, 4664-4671. [CrossRef] [PubMed]

49. Etienne, L.; Hahn, B.H.; Sharp, P.M.; Matsen, F.A.; Emerman, M. Gene loss and adaptation to hominids underlie the ancient origin of HIV-1. Cell Host Microbe 2013, 14, 85-92. [CrossRef] [PubMed]

50. Bell, S.M.; Bedford, T. Modern-day SIV viral diversity generated by extensive recombination and cross-species transmission. PLoS Pathog. 2017, 13, 1-21. [CrossRef]

51. Filomatori, C.V.; Bardossy, E.S.; Merwaiss, F.; Suzuki, Y.; Henrion, A.; Saleh, M.C.; Alvarez, D.E. RNA recombination at Chikungunya virus $3^{\prime}$ UTR as an evolutionary mechanism that provides adaptability. PLoS Pathog. 2019, 15, 1007706. [CrossRef]

52. Becher, P.; Tautz, N. RNA recombination in pestiviruses-Cellular RNA sequences in viral genomes highlight the role of host factors for viral persistence and lethal disease. RNA Biol. 2011, 8, 37-41. [CrossRef]

53. Khatchikian, D.; Orlich, M.; Rott, R. Increased viral pathogenicity after insertion of a 28S ribosomal RNA sequence into the haemagglutinin gene of an influenza virus. Nature 1989, 340, 156-157. [CrossRef]

54. Herrewegh, A.A.; Vennema, H.; Horzinek, M.C.; Rottier, P.J.M.; De Groot, R.J. The molecular genetics of feline coronaviruses: Comparative sequence analysis of the ORF7a/7b transcription unit of different biotypes. Virology 1995, 212, 622-631. [CrossRef]

55. Fernández-Cuartero, B.; Burgyán, J.; Aranda, M.A.; Salänki, K.; Moriones, E.; Garcı-Arenal, F. Increase in the Relative Fitness of a Plant Virus RNA Associated with Its Recombinant Nature. Virology 1994, 203, 373-377. [CrossRef] [PubMed]

56. Pilipenko, E.V.; Gmyl, A.P.; Maslova, S.V.; Svitkin, Y.V.; Sinyakov, A.N.; Agol, V.I. Prokaryotic-like cis elements in the cap-independent internal initiation of translation on picornavirus RNA. Cell 1992, 68, 119-131. [CrossRef]

57. Chen, Y.; Goldbach, R.; Prins, M. Inter- and Intramolecular Recombinations in the Cucumber Mosaic Virus Genome Related to Adaptation to Alstroemeria. J. Virol. 2002, 76, 4119-4124. [CrossRef] [PubMed] 
58. Erickson, A.K.; Jesudhasan, P.R.; Mayer, M.J.; Narbad, A.; Winter, S.E.; Pfeiffer, J.K. Bacteria Facilitate Enteric Virus Co-infection of Mammalian Cells and Promote Genetic Recombination. Cell Host Microbe 2018, 23, 77-88. [CrossRef] [PubMed]

59. Rowlands, D.J.; Minor, P.D. Vaccine Strategies. In The Picornaviruses; Ehrenfeld, E., Dominog, E., Roos, R.P., Eds.; ASM Press: Washington, DC, USA, 2010; pp. 431-447.

60. Kew, O.M.; Sutter, R.W.; de Gourville, E.M.; Dowdle, W.R.; Pallansch, M.A. Vaccine-Derived Polioviruses and the Endgame Strategy for Global Polio Eradication. Annu. Rev. Microbiol. 2005, 59, 587-635. [CrossRef]

61. Combelas, N.; Holmblat, B.; Joffret, M.L.; Colbère-Garapin, F.; Delpeyroux, F. Recombination between poliovirus and coxsackie A viruses of species C: A model of viral genetic plasticity and emergence. Viruses 2011, 3, 1460-1484. [CrossRef] [PubMed]

62. Burns, C.C.; Diop, O.M.; Sutter, R.W.; Kew, O.M. Vaccine-derived polioviruses. J. Infect. Dis. 2014, 210, S283-S293. [CrossRef]

63. Pons-Salort, M.; Burns, C.C.; Lyons, H.; Blake, I.M.; Jafari, H.; Oberste, M.S.; Kew, O.M.; Grassly, N.C. Preventing Vaccine-Derived Poliovirus Emergence during the Polio Endgame. PLoS Pathog. 2016, 12, 1-18. [CrossRef]

64. WHO Circulating Vaccine-Derived Polioviruses. Available online: http://polioeradication.org/polio-today/ polio-now/this-week/circulating-vaccine-derived-poliovirus/ (accessed on 7 May 2019).

65. Rakoto-Andrianarivelo, M.; Guillot, S.; Iber, J.; Balanant, J.; Blondel, B.; Riquet, F.; Martin, J.; Kew, O.; Randriamanalina, B.; Razafinimpiasa, L.; et al. Co-circulation and evolution of polioviruses and species C enteroviruses in a district of Madagascar. PLoS Pathog. 2007, 3, 1950-1961. [CrossRef]

66. Rakoto-Andrianarivelo, M.; Gumede, N.; Jegouic, S.; Balanant, J.; Andriamamonjy, S.N.; Rabemanantsoa, S.; Birmingham, M.; Randriamanalina, B.; Nkolomoni, L.; Venter, M.; et al. Reemergence of Recombinant Vaccine-Derived Poliovirus Outbreak in Madagascar. J. Infect. Dis. 2008, 197, 1427-1435. [CrossRef]

67. Dedepsidis, E.; Kyriakopoulou, Z.; Pliaka, V.; Kottaridi, C.; Bolanaki, E.; Levidiotou-Stefanou, S.; Komiotis, D.; Markoulatos, P. Retrospective characterization of a vaccine-derived poliovirus type 1 isolate from sewage in Greece. Appl. Environ. Microbiol. 2007, 73, 6697-6704. [CrossRef] [PubMed]

68. Kew, O.; Morris-Glasgow, V.; Landaverde, M.; Burns, C.; Shaw, J.; Garib, Z.; André, J.; Blackman, E.; Freeman, C.J.; Jorba, J.; et al. Outbreak of poliomyelitis in hispaniola associated with circulating type 1 vaccine-derived poliovirus. Science 2002, 296, 356-359. [CrossRef] [PubMed]

69. Shimizu, H.; Thorley, B.; Paladin, F.J.; Brussen, K.A.; Stambos, V.; Yuen, L.; Utama, A.; Tano, Y.; Arita, M.; Yoshida, H.; et al. Circulation of Type 1 Vaccine-Derived Poliovirus in the Philippines in 2001. J. Virol. 2004, 78, 13512-13521. [CrossRef] [PubMed]

70. Joffret, M.L.; Jégouic, S.; Bessaud, M.; Balanant, J.; Tran, C.; Caro, V.; Holmblat, B.; Razafindratsimandresy, R.; Reynes, J.M.; Rakoto-Andrianarivelo, M.; et al. Common and diverse features of cocirculating type 2 and 3 recombinant vaccine-derived polioviruses isolated from patients with poliomyelitis and healthy children. J. Infect. Dis. 2012, 205, 1363-1373. [CrossRef] [PubMed]

71. Adu, F.; Iber, J.; Bukbuk, D.; Gumede, N.; Yang, S.J.; Jorba, J.; Campagnoli, R.; Sule, W.F.; Yang, C.F.; Burns, C.; et al. Isolation of recombinant type 2 vaccine-derived poliovirus (VDPV) from a Nigerian child. Virus Res. 2007, 127, 17-25. [CrossRef] [PubMed]

72. Burns, C.C.; Shaw, J.; Jorba, J.; Bukbuk, D.; Adu, F.; Gumede, N.; Pate, M.A.; Abanida, E.A.; Gasasira, A.; Iber, J.; et al. Multiple Independent Emergences of Type 2 Vaccine-Derived Polioviruses during a Large Outbreak in Northern Nigeria. J. Virol. 2013, 87, 4907-4922. [CrossRef] [PubMed]

73. Yang, C.-F.; Naguib, T.; Yang, S.-J.; Nasr, E.; Jorba, J.; Ahmed, N.; Campagnoli, R.; van der Avoort, H.; Shimizu, H.; Yoneyama, T.; et al. Circulation of endemic type 2 vaccine-derived poliovirus in Egypt from 1983 to 1993. J. Virol. 2003, 77, 8366-8377. [CrossRef] [PubMed]

74. Jiang, P.; Faase, J.A.J.; Toyoda, H.; Paul, A.; Wimmer, E.; Gorbalenya, A.E. Evidence for emergence of diverse polioviruses from C-cluster coxsackie A viruses and implications for global poliovirus eradication. Proc. Natl. Acad. Sci. USA 2007, 104, 9457-9462. [CrossRef]

75. Riquet, F.B.; Blanchard, C.; Jegouic, S.; Balanant, J.; Guillot, S.; Vibet, M.-A.; Rakoto-Andrianarivelo, M.; Delpeyroux, F. Impact of exogenous sequences on the characteristics of an epidemic type 2 recombinant vaccine-derived poliovirus. J. Virol. 2008, 82, 8927-8932. [CrossRef]

76. Jegouic, S.; Joffret, M.L.; Blanchard, C.; Riquet, F.B.; Perret, C.; Pelletier, I.; Colbere-Garapin, F.; Rakoto-Andrianarivelo, M.; Delpeyroux, F. Recombination between polioviruses and co-circulating coxsackie 
A viruses: Role in the emergence of pathogenic vaccine-derived polioviruses. PLoS Pathog. 2009, 5, 1000412. [CrossRef]

77. Muslin, C.; Joffret, M.-L.; Pelletier, I.; Blondel, B.; Delpeyroux, F. Evolution and Emergence of Enteroviruses through Intra- and Inter-species Recombination: Plasticity and Phenotypic Impact of Modular Genetic Exchanges in the 5' Untranslated Region. PLoS Pathog. 2015, 11, 1005266. [CrossRef] [PubMed]

78. Bessaud, M.; Joffret, M.L.; Blondel, B.; Delpeyroux, F. Exchanges of genomic domains between poliovirus and other cocirculating species $C$ enteroviruses reveal a high degree of plasticity. Sci. Rep. 2016, 6, 1-12. [CrossRef] [PubMed]

79. Kirkegaard, K.; Baltimore, D. The mechanism of RNA recombination in poliovirus. Cell 1986, 47, 433-443. [CrossRef]

80. Oprisan, G.; Combiescu, M.; Guillot, S.; Caro, V.; Combiescu, A.; Delpeyroux, F.; Crainic, R. Natural genetic recombination between co-circulating heterotypic enteroviruses. J. Gen. Virol. 2002, 83, 2193-2200. [CrossRef] [PubMed]

81. Chevaliez, S.; Szendröi, A.; Caro, V.; Balanant, J.; Guillot, S.; Berencsi, G.; Delpeyroux, F. Molecular comparison of echovirus 11 strains circulating in Europe during an epidemic of multisystem hemorrhagic disease of infants indicates that evolution generally occurs by recombination. Virology 2004, 325, 56-70. [CrossRef] [PubMed]

82. Fernandez-Garcia, M.D.; Volle, R.; Joffret, M.L.; Sadeuh-Mba, S.A.; Gouandjika-Vasilache, I.; Kebe, O.; Wiley, M.R.; Majumdar, M.; Simon-Loriere, E.; Sakuntabhai, A.; et al. Genetic characterization of enterovirus A71 circulating in Africa. Emerg. Infect. Dis. 2018, 24, 754-757. [CrossRef] [PubMed]

83. Lukashev, A.N.; Lashkevich, V.A.; Ivanova, O.E.; Koroleva, G.A.; Hinkkanen, A.E.; Ilonen, J. Recombination in circulating enteroviruses. J. Virol. 2003, 77, 10423-10431. [CrossRef]

84. McWilliam Leitch, E.C.; Cabrerizo, M.; Cardosa, J.; Harvala, H.; Ivanova, O.E.; Koike, S.; Kroes, A.C.M.; Lukashev, A.; Perera, D.; Roivainen, M.; et al. The Association of Recombination Events in the Founding and Emergence of Subgenogroup Evolutionary Lineages of Human Enterovirus 71. J. Virol. 2012, 86, 2676-2685. [CrossRef]

85. Lindberg, A.M.; Andersson, P.; Savolainen, C.; Mulders, M.N.; Hovi, T. Evolution of the genome of Human enterovirus B: Incongruence between phylogenies of the VP1 and 3CD regions indicates frequent recombination within the species. J. Gen. Virol. 2003, 84, 1223-1235. [CrossRef]

86. Bessaud, M.; Joffret, M.L.; Holmblat, B.; Razafindratsimandresy, R.; Delpeyroux, F. Genetic relationship between cocirculating human enteroviruses species C. PLoS ONE 2011, 6, e24823. [CrossRef]

87. Kyriakopoulou, Z.; Pliaka, V.; Amoutzias, G.D.; Markoulatos, P. Recombination among human non-polio enteroviruses: Implications for epidemiology and evolution. Virus Genes 2015, 50, 177-188. [CrossRef]

88. Tan, Y.; Hassan, F.; Schuster, J.E.; Simenauer, A.; Selvarangan, R.; Halpin, R.A.; Lin, X.; Fedorova, N.; Stockwell, T.B.; Lam, T.T.-Y.; et al. Molecular Evolution and Intraclade Recombination of Enterovirus D68 during the 2014 Outbreak in the United States. J. Virol. 2016, 90, 1997-2007. [CrossRef] [PubMed]

89. Yang, Q.; Zhang, Y.; Yan, D.; Zhu, S.; Wang, D.; Ji, T.; Li, X.; Song, Y.; Gu, X.; Xu, W. Two genotypes of coxsackievirus A2 associated with hand, foot, and mouth disease circulating in China since 2008. PLoS ONE 2016, 11, 1-12. [CrossRef] [PubMed]

90. Hassel, C.; Mirand, A.; Farkas, A.; Diedrich, S.; Huemer, H.P.; Peigue-Lafeuille, H.; Archimbaud, C.; Henquell, C.; Bailly, J.-L.; Network, H.F.S. Phylogeography of Coxsackievirus A16 Reveals Global Transmission Pathways and Recent Emergence and Spread of a Recombinant Genogroup. J. Virol. 2017, 91, 1-16. [CrossRef] [PubMed]

91. Worobey, M.; Holmes, E.C. Evolutionary aspects of recombination in RNA viruses. J. Gen. Virol. 1999, 80, 2535-2543. [CrossRef] [PubMed]

92. Kumar, A.; Shukla, D.; Srivastava, S.; Idris, M.Z.; Dhole, T.N. High frequency of enterovirus serotype circulation in a densely populated area of India. J. Infect. Dev. Ctries. 2013, 7, 475-483. [CrossRef] [PubMed]

93. Sadeuh-Mba, S.A.; Bessaud, M.; Massenet, D.; Joffret, M.L.; Endegue, M.C.; Njouom, R.; Reynes, J.M.; Rousset, D.; Delpeyroux, F. High frequency and diversity of species C enteroviruses in Cameroon and neighboring countries. J. Clin. Microbiol. 2013, 51, 759-770. [CrossRef] [PubMed]

94. Thoelen, I.; Lemey, P.; Van der Donck, I.; Beuselinck, K.; Lindberg, A.M.; Van Ranst, M. Molecular typing and epidemiology of enteroviruses identified from an outbreak of aseptic meningitis in Belgium during the summer of 2000. J. Med. Virol. 2003, 70, 420-429. [CrossRef] [PubMed] 
95. Volle, R.; Bailly, J.-L.; Mirand, A.; Pereira, B.; Marque-Juillet, S.; Chambon, M.; Regagnon, C.; Brebion, A.; Henquell, C.; Peigue-Lafeuille, H.; et al. Variations in Cerebrospinal Fluid Viral Loads Among Enterovirus Genotypes in Patients Hospitalized With Laboratory-Confirmed Meningitis Due to Enterovirus. J. Infect. Dis. 2014, 210, 576-584. [CrossRef]

96. Mirand, A.; Henquell, C.; Archimbaud, C.; Chambon, M.; Charbonne, F.; Peigue-Lafeuille, H.; Bailly, J.L. Prospective identification of enteroviruses involved in meningitis in 2006 through direct genotyping in cerebrospinal fluid. J. Clin. Microbiol. 2008, 46, 87-96. [CrossRef]

97. Volle, R.; Razafindratsimandresy, R.; Joffret, M.L.; Bessaud, M.; Rabemanantsoa, S.; Andriamamonjy, S.; Raharinantoanina, J.; Blondel, B.; Heraud, J.-M.; Bailly, J.-L.; et al. High permissiveness for genetic exchanges between enteroviruses of species A, including enterovirus 71, favours evolution through intertypic recombination in Madagascar. J. Virol. 2019, 93, e01667-18. [CrossRef] [PubMed]

98. Han, J.F.; Zhang, Y.; Hou, P.Q.; Zhu, S.Y.; Wu, X.Y.; Zhao, H.; Yu, M.; Qin, C.F. Human enterovirus co-infection in severe HFMD patients in China. J. Clin. Virol. 2014, 61, 621-622. [CrossRef] [PubMed]

99. Aguilera, E.R.; Erickson, A.K.; Jesudhasan, P.R.; Robinson, C.M.; Pfeiffer, J.K. Plaques formed by mutagenized viral populations have elevated coinfection frequencies. MBio 2017, 8, 1-12. [CrossRef] [PubMed]

100. Chen, Y.; Du, W.; Hagemeijer, M.C.; Takvorian, P.M.; Pau, C.; Cali, A.; Brantner, C.A. Phosphatidylserine Vesicles Enable Efficient En Bloc Transmission of Enteroviruses. Cell 2015, 160, 619-630. [CrossRef] [PubMed]

101. Egger, D.; Bienz, K. Recombination of poliovirus RNA proceeds in mixed replication complexes originating from distinct replication start sites. J. Virol. 2002, 76, 10960-10971. [CrossRef] [PubMed]

102. Garcia-Ruiz, H.; Diaz, A.; Ahlquist, P. Intermolecular RNA Recombination Occurs at Different Frequencies in Alternate Forms of Brome Mosaic Virus RNA Replication Compartments. Viruses 2018, 10, 131. [CrossRef] [PubMed]

103. Belov, G.A.; Nair, V.; Hansen, B.T.; Hoyt, F.H.; Fischer, E.R.; Ehrenfeld, E. Complex Dynamic Development of Poliovirus Membranous Replication Complexes. J. Virol. 2012, 86, 302-312. [CrossRef] [PubMed]

104. Santti, J.; Hyypiä, T.; Kinnunen, L.; Salminen, M. Evidence of recombination among enteroviruses. J. Virol. 1999, 73, 8741-8749. [PubMed]

105. Brown, B.; Oberste, M.S.; Maher, K.; Mark, A.; Pallansch, M.A. Complete Genomic Sequencing Shows that Polioviruses and Members of Human Enterovirus Species C Are Closely Related in the Noncapsid Coding Region. J. Virol. 2003, 77, 8973-8984. [CrossRef]

106. Lukashev, A.N. Role of recombination in evolution of enteroviruses. Rev. Med. Virol. 2005, 15, 157-167. [CrossRef]

107. Oberste, M.S.; Peñaranda, S.; Pallansch, M.A. RNA recombination plays a major role in genomic change during circulation of coxsackie B viruses. J. Virol. 2004, 78, 2948-2955. [CrossRef] [PubMed]

108. Nikolaidis, M.; Mimouli, K.; Kyriakopoulou, Z.; Tsimpidis, M.; Tsakogiannis, D.; Markoulatos, P.; Amoutzias, G.D. Large-scale genomic analysis reveals recurrent patterns of intertypic recombination in human enteroviruses. Virology 2019, 526, 72-80. [CrossRef] [PubMed]

109. Oberste, M.S.; Peñaranda, S.; Maher, K.; Pallansch, M.A. Complete genome sequences of all members of the species Human enterovirus A. J. Gen. Virol. 2004, 85, 1597-1607. [CrossRef] [PubMed]

110. Oberste, M.S.; Maher, K.; Pallansch, M.A. Evidence for frequent recombination within species human enterovirus B based on complete genomic sequences of all thirty-seven serotypes. J. Virol. 2004, 78, 855-867. [CrossRef] [PubMed]

111. Simmonds, P.; Welch, J. Frequency and Dynamics of Recombination within Different Species of Human Enteroviruses. J. Virol. 2006, 80, 483-493. [CrossRef]

112. Bouslama, L.; Nasri, D.; Chollet, L.; Belguith, K.; Bourlet, T.; Aouni, M.; Pozzetto, B.; Pillet, S. Natural recombination event within the capsid genomic region leading to a chimeric strain of human enterovirus B. J. Virol. 2007, 81, 8944-8952. [CrossRef]

113. Martín, J.; Samoilovich, E.; Dunn, G.; Lackenby, A.; Feldman, E.; Heath, A.; Svirchevskaya, E.; Cooper, G.; Yermalovich, M.; Minor, P.D. Isolation of an Intertypic Poliovirus Capsid Recombinant from a Child with Vaccine-Associated Paralytic Poliomyelitis. J. Virol. 2002, 76, 10921-10928. [CrossRef]

114. Xiao, H.; Huang, K.; Li, L.; Wu, X.; Zheng, L.; Wan, C.; Zhao, W.; Ke, C.; Zhang, B. Complete genome sequence analysis of human echovirus 30 isolated during a large outbreak in Guangdong Province of China, in 2012. Arch. Virol. 2014, 159, 379-383. [CrossRef] 
115. Zhang, Y.; Zhu, S.; Yan, D.; Liu, G.; Bai, R.; Wang, D.; Chen, L.; Zhu, H.; An, H.; Kew, O.; et al. Natural type 3/type 2 intertypic vaccine-related poliovirus recombinants with the first crossover sites within the VP1 capsid coding region. PLoS ONE 2010, 5, 1-11. [CrossRef]

116. Blomqvist, S.; Bruu, A.-L.; Stenvik, M.; Hovi, T. Characterization of a recombinant type 3/type 2 poliovirus isolated from a healthy vaccinee and containing a chimeric capsid protein VP1. J. Gen. Virol. 2003, 84, 573-580. [CrossRef]

117. Korotkova, E.; Laassri, M.; Zagorodnyaya, T.; Petrovskaya, S.; Rodionova, E.; Cherkasova, E.; Gmyl, A.; Ivanova, O.E.; Eremeeva, T.P.; Lipskaya, G.Y.; et al. Pressure for pattern-specific intertypic recombination between sabin polioviruses: Evolutionary implications. Viruses 2017, 9, 353. [CrossRef]

118. Lukashev, A.N.; Elena, Y.; Belalov, I.S.; Ivanova, O.E.; Eremeeva, T.P.; Reznik, V.I.; Trotsenko, O.E.; Drexler, J.F.; Drosten, C. Recombination strategies and evolutionary dynamics of the Human enterovirus A global gene pool. J. Gen. Virol. 2014, 95, 868-873. [CrossRef] [PubMed]

119. Smura, T.; Blomqvist, S.; Vuorinen, T.; Ivanova, O.; Samoilovich, E.; Al-Hello, H.; Savolainen-Kopra, C.; Hovi, T.; Roivainen, M. Recombination in the evolution of enterovirus $C$ species sub-group that contains types CVA-21, CVA-24, EV-C95, EV-C96 and EV-C99. PLoS ONE 2014, 9, e94579. [CrossRef]

120. Arita, M.; Zhu, S.-L.; Yoshida, H.; Yoneyama, T.; Miyamura, T.; Shimizu, H. A Sabin 3-Derived Poliovirus Recombinant Contained a Sequence Homologous with Indigenous Human Enterovirus Species C in the Viral Polymerase Coding Region. J. Virol. 2005, 79, 12650-12657. [CrossRef] [PubMed]

121. Lowry, K.; Woodman, A.; Cook, J.; Evans, D.J. Recombination in Enteroviruses is a Biphasic Replicative Process Involving the Generation of Greater-than Genome Length "Imprecise" Intermediates. PLoS Pathog. 2014, 10, 1004191. [CrossRef] [PubMed]

122. Holmblat, B.; Jégouic, S.; Muslin, C.; Blondel, B.; Joffret, M.-L.; Delpeyroux, F. Nonhomologous recombination between defective poliovirus and coxsackievirus genomes suggests a new model of genetic plasticity for picornaviruses. MBio 2014, 5, e01119-14. [CrossRef]

123. McWilliam Leitch, E.C.; Bendig, J.; Cabrerizo, M.; Cardosa, J.; Hyypia, T.; Ivanova, O.E.; Kelly, A.; Kroes, A.C.M.; Lukashev, A.; MacAdam, A.; et al. Transmission Networks and Population Turnover of Echovirus 30. J. Virol. 2009, 83, 2109-2118. [CrossRef]

124. Gmyl, A.P.; Belousov, E.V.; Maslova, S.V.; Khitrina, E.V.; Chetverin, A.B.; Agol, V.I. Nonreplicative RNA recombination in poliovirus. J. Virol. 1999, 73, 8958-8965. [PubMed]

125. Nagy, P.D.; Simon, A.E. New Insights into the Mechanisms of RNA Recombination. Virology 1997, 235, 1-9. [CrossRef]

126. Simon-Loriere, E.; Holmes, E.C. Why do RNA viruses recombine? Nat. Rev. Microbiol. 2011, 9, $617-626$. [CrossRef] [PubMed]

127. Cooper, P.D.; Steiner-Pryor, A.; Scotti, P.D.; Delong, D. On the Nature of Poliovirus Genetic Recombinants. J. Gen. Virol. 1974, 23, 41-49. [CrossRef] [PubMed]

128. Galetto, R.; Negroni, M. Mechanistic features of recombination in HIV. AIDS Rev. 2005, 7, 92-102. [PubMed]

129. Lai, M.M. RNA recombination in animal and plant viruses. Microbiol. Rev. 1992, 56, 61-79. [PubMed]

130. Arnold, J.J.; Cameron, C.E. Poliovirus RNA-dependent RNA Polymerase (3D pol) Is Sufficient for Template Switching in Vitro. J. Biol. Chem. 1999, 274, 2706-2716. [CrossRef] [PubMed]

131. Flanegan, J.B.; Baltimore, D. Poliovirus-specific primer-dependent RNA polymerase able to copy poly(A). Proc. Natl. Acad. Sci. USA 1977, 74, 3677-3680. [CrossRef] [PubMed]

132. Cho, M.W.; Richards, O.C.; Dmitrieva, T.M.; Agol, V.; Ehrenfeld, E. RNA duplex unwinding activity of poliovirus RNA-dependent RNA polymerase 3D(pol). J. Virol. 1993, 67, 3010-3018. [PubMed]

133. Chetverin, A.B.; Kopein, D.S.; Chetverina, H.V.; Demidenko, A.A.; Ugarov, V.I. Viral RNA-directed RNA polymerases use diverse mechanisms to promote recombination between RNA molecules. J. Biol. Chem. 2005, 280, 8748-8755. [CrossRef] [PubMed]

134. Woodman, A.; Arnold, J.J.; Cameron, C.E.; Evans, D.J. Biochemical and genetic analysis of the role of the viral polymerase in enterovirus recombination. Nucleic Acids Res. 2016, 44, 6883-6895. [CrossRef]

135. Kempf, B.J.; Peersen, O.B.; Barton, D.J. Poliovirus Polymerase Leu420 Facilitates RNA Recombination and Ribavirin Resistance. J. Virol. 2016, 90, 8410-8421. [CrossRef]

136. Gmyl, A.P.; Agol, V.I. Diverse mechanisms of RNA recombination. Mol. Biol. 2005, 39, 529-542. [CrossRef]

137. Kuge, S.; Saito, I.; Nomoto, A. Primary structure of poliovirus defective-interfering particle genomes and possible generation mechanisms of the particles. J. Mol. Biol. 1986, 192, 473-487. [CrossRef] 
138. Li, Y.; Ball, L. A Nonhomologous RNA recombination during negative-strand synthesis of flock house virus RNA. J. Virol. 1993, 67, 3854-3860. [PubMed]

139. King, A.M. Preferred sites of recombination in poliovirus RNA: An analysis of 40 intertypic cross-over sequences. Nucleic Acids Res. 1988, 16, 11705-11723. [CrossRef] [PubMed]

140. Cascone, P.J.; Carpenter, C.D.; Li, X.H.; Simon, A.E. Recombination between satellite and genomic RNAs of turnip crinkle virus. Virology 1990, 184, 791-794.

141. Carpenter, C.D.; Oh, J.; Zhang, C.; Simon, A.E. Involvement of a Stem-loop Structure in the Location of Junction Sites in Viral RNA Recombination. J. Mol. Biol. 1995, 245, 608-622. [CrossRef] [PubMed]

142. Dzianott, A.; Rauffer-Bruyere, N.; Bujarski, J.J. Studies on functional interaction between brome mosaic virus replicase proteins during RNA recombination, using combined mutants in vivo and in vitro. Virology 2001, 289, 137-149. [CrossRef]

143. Olsthoorn, R.C.L.; Bruyere, A.; Dzianott, A.; Bujarski, J.J. RNA recombination in brome mosaic virus: Effects of strand-specific stem-loop inserts. J. Virol. 2002, 76, 12654-12662. [CrossRef] [PubMed]

144. Fitzsimmons, W.J.; Woods, R.J.; McCrone, J.T.; Woodman, A.; Arnold, J.J.; Yennawar, M.; Evans, R.; Cameron, C.E.; Lauring, A.S. A speed-fidelity trade-off determines the mutation rate and virulence of an RNA virus. PLoS Biol. 2018, 16, 1-20. [CrossRef] [PubMed]

145. Kautz, T.F.; Forrester, N.L. RNA Virus Fidelity Mutants: A Useful Tool for Evolutionary Biology or a Complex Challenge? Viruses 2018, 10, 1-17. [CrossRef]

146. Dulin, D.; Vilfan, I.D.; Berghuis, B.A.; Hage, S.; Bamford, D.H.; Poranen, M.M.; Depken, M.; Dekker, N.H. Elongation-Competent Pauses Govern the Fidelity of a Viral RNA-Dependent RNA Polymerase. Cell Rep. 2015, 10, 983-992. [CrossRef]

147. Dulin, D.; Arnold, J.J.; van Laar, T.; Oh, H.-S.; Lee, C.; Perkins, A.L.; Harki, D.A.; Depken, M.; Cameron, C.E.; Dekker, N.H. Signatures of Nucleotide Analog Incorporation by an RNA-Dependent RNA Polymerase Revealed Using High-Throughput Magnetic Tweezers. Cell Rep. 2017, 21, 1063-1076. [CrossRef] [PubMed]

148. Roda, R.H.; Balakrishnan, M.; Kim, J.K.; Roques, B.P.; Fay, P.J.; Bambara, R.A. Strand transfer occurs in retroviruses by a pause-initiated two-step mechanism. J. Biol. Chem. 2002, 277, 46900-46911. [CrossRef] [PubMed]

149. White, K.A.; Morris, T.J. RNA determinants of junction site selection in RNA virus recombinants and defective interfering RNAs. RNA 1995, 1, 105-109.

150. Gao, L.; Balakrishnan, M.; Roques, B.P.; Bambara, R.A. Insights into the multiple roles of pausing in HIV-1 reverse transcriptase-promoted strand transfers. J. Biol. Chem. 2007, 282, 6222-6231. [CrossRef] [PubMed]

151. Simon-Loriere, E.; Martin, D.P.; Weeks, K.M.; Negroni, M. RNA Structures Facilitate Recombination-Mediated Gene Swapping in HIV-1. J. Virol. 2010, 84, 12675-12682. [CrossRef] [PubMed]

152. Dedepsidis, E.; Kyriakopoulou, Z.; Pliaka, V.; Markoulatos, P. Correlation between recombination junctions and RNA secondary structure elements in poliovirus Sabin strains. Virus Genes 2010, 41, 181-191. [CrossRef]

153. Runckel, C.; Westesson, O.; Andino, R.; DeRisi, J.L. Identification and Manipulation of the Molecular Determinants Influencing Poliovirus Recombination. PLoS Pathog. 2013, 9, 1003164. [CrossRef]

154. Tolskaya, E.A.; Romanova, L.I.; Blinov, V.M.; Viktorova, E.G.; Sinyakov, A.N.; Kolesnikova, M.S.; Agol, V.I. Studies on the recombination between RNA genomes of poliovirus: The primary structure and nonrandom distribution of crossover regions in the genomes of intertypic poliovirus recombinants. Virology 1987, 161, 54-61. [CrossRef]

155. Romanova, L.I.; Blinov, V.M.; Tolskaya, E.A.; Viktorova, E.G.; Kolesnikova, M.S.; Guseva, E.A.; Agol, V.I. The primary structure of crossover regions of intertypic poliovirus recombinants: A model of recombination between RNA genomes. Virology 1986, 155, 202-213. [CrossRef]

156. Bujarski, J.J.; Dzianott, A.M. Generation and analysis of nonhomologous RNA-RNA recombinants in brome mosaic virus: Sequence complementarities at crossover sites. J. Virol. 1991, 65, 4153-4159.

157. Meyers, G.; Tautz, N.; Dubovi, E.J.; Thiel, H.J. Viral cytopathogenicity correlated with integration of ubiquitin-coding sequences. Virology 1991, 180, 602-616. [CrossRef]

158. Nagy, P.D.; Bujarski, J.J. Targeting the site of RNA-RNA recombination in brome mosaic virus with antisense sequences. Proc. Natl. Acad. Sci. USA 1993, 90, 6390-6394. [CrossRef] [PubMed]

159. Kim, M.J.; Kao, C. Factors regulating template switch in vitro by viral RNA-dependent RNA polymerases: Implications for RNA-RNA recombination. Proc. Natl. Acad. Sci. USA 2001, 98, 4972-4977. [CrossRef] [PubMed] 
160. Nagy, P.D.; Bujarski, J.J. Homologous RNA recombination in brome mosaic virus: AU-rich sequences decrease the accuracy of crossovers. J Virol. 1996, 70, 415-426. [PubMed]

161. Nagy, P.D.; Bujarski, J.J. Engineering of homologous recombination hotspots with AU-rich sequences in brome mosaic virus. J. Virol. 1997, 71, 3799-3810. [PubMed]

162. Shapka, N.; Nagy, P.D. The AU-rich RNA recombination hot spot sequence of Brome mosaic virus is functional in tombusviruses: Implications for the mechanism of RNA recombination. J. Virol. 2004, 78, 2288-2300. [CrossRef] [PubMed]

163. Pilipenko, E.V.; Gmyl, A.P.; Agol, V.I. A model for rearrangements in RNA genomes. Nucleic Acids Res. 1995, 23, 1870-1875. [CrossRef] [PubMed]

164. Gallei, A.; Orlich, M.; Thiel,H.; Becher, P. Noncytopathogenic Pestivirus Strains Generated by Nonhomologous RNA Recombination: Alterations in the NS4A/NS4B Coding Region. Society 2005, 79, 14261-14270. [CrossRef] [PubMed]

165. Nagy, P.D.; Bujarski, J.J. Efficient system of homologous RNA recombination in brome mosaic virus: Sequence and structure requirements and accuracy of crossovers. J. Virol. 1995, 69, 131-140.

166. Nagy, P.D. The roles of host factors in tombusvirus rna recombination. Adv. Virus Res. 2011, 81, 63-84.

167. Chuang, C.; Prasanth, K.R.; Nagy, P.D. Coordinated Function of Cellular DEAD-Box Helicases in Suppression of Viral RNA Recombination and Maintenance of Viral Genome Integrity. PLoS Pathog. 2015, 11, 1-25. [CrossRef] [PubMed]

168. Prasanth, K.R.; Kovalev, N.; de Castro Martín, I.F.; Baker, J.; Nagy, P.D. Screening a yeast library of temperature-sensitive mutants reveals a role for actin in tombusvirus RNA recombination. Virology 2016, 489, 233-242. [CrossRef] [PubMed]

169. Zhang, X.; Nuss, D.L. A host dicer is required for defective viral RNA production and recombinant virus vector RNA instability for a positive sense RNA virus. Proc. Natl. Acad. Sci. USA 2008, 105, 16749-16754. [CrossRef] [PubMed]

170. Sun, Q.; Choi, G.H.; Nuss, D.L. A single Argonaute gene is required for induction of RNA silencing antiviral defense and promotes viral RNA recombination. Proc. Natl. Acad. Sci. USA 2009, 106, 17927-17932. [CrossRef] [PubMed]

171. Chetverin, A.B.; Chetverina, H.V.; Demidenko, A.A.; Ugarov, V.I. Nonhomologous RNA recombination in a cell-free system: Evidence for a transesterification mechanism guided by secondary structure. Cell 1997, 88, 503-513. [CrossRef]

172. Chetverina, H.V.; Demidenko, A.A.; Ugarov, V.I.; Chetverin, A.B. Spontaneous rearrangements in RNA sequences. FEBS Lett. 1999, 450, 89-94. [CrossRef]

173. Gmyl, A.P.; Korshenko, S.A.; Belousov, E.V.; Khitrina, E.V.; Agol, V.I. Nonreplicative homologous RNA recombination: Promiscuous joining of RNA pieces? RNA 2003, 9, 1221-1231. [CrossRef] [PubMed]

174. Gallei, A.; Pankraz, A.; Thiel, H.-J.; Becher, P. RNA Recombination In Vivo in the Absence of Viral Replication. J. Virol. 2004, 78, 6271-6281. [CrossRef] [PubMed]

175. Austermann-Busch, S.; Becher, P. RNA Structural Elements Determine Frequency and Sites of Nonhomologous Recombination in an Animal Plus-Strand RNA Virus. J. Virol. 2012, 86, 7393-7402. [CrossRef]

176. Scheel, T.K.H.; Galli, A.; Li, Y.P.; Mikkelsen, L.S.; Gottwein, J.M.; Bukh, J. Productive Homologous and Non-homologous Recombination of Hepatitis C Virus in Cell Culture. PLoS Pathog. 2013, 9, 1-12. [CrossRef]

177. Kleine-Büning, M.; Meyer, D.; Austermann-Busch, S.; Roman-Sosa, G.; Rümenapf, T.; Becher, P. Nonreplicative RNA recombination of an animal plus-strand RNA virus in the absence of efficient translation of viral proteins. Genome Biol. Evol. 2017, 9, 817-829. [CrossRef] [PubMed]

178. Li, W.M.; Barnes, T.; Lee, C.H. Endoribonucleases-enzymes gaining spotlight in mRNA metabolism. FEBS J. 2010, 277, 627-641. [CrossRef] [PubMed]

179. Popow, J.; Schleiffer, A.; Martinez, J. Diversity and roles of (t)RNA ligases. Cell. Mol. Life Sci. 2012, 69, 2657-2670. [CrossRef] [PubMed]

180. Lutay, A.V.; Zenkova, M.A.; Vlassov, V.V. Nonenzymatic Recombination of RNA: Possible Mechanism for the Formation of Novel Sequences. Chem. Biodivers. 2007, 4, 762-767. [PubMed]

181. Nechaev, S.; Lutay, A.; Vlassov, V.; Zenkova, M.; Nechaev, S.Y.; Lutay, A.V.; Vlassov, V.V.; Zenkova, M.A. Non-Enzymatic Template-Directed Recombination of RNAs. Int. J. Mol. Sci. 2009, 10, 1788-1807. [PubMed]

182. Staroseletz, Y.; Nechaev, S.; Bichenkova, E.; Bryce, R.A.; Watson, C.; Vlassov, V.; Zenkova, M. Non-enzymatic recombination of RNA: Ligation in loops. Biochim. Biophys. Acta Gen. Subj. 2018, 1862, 705-725. [CrossRef] 
183. Mutschler, H.; Taylor, A.I.; Porebski, B.T.; Lightowlers, A.; Houlihan, G.; Abramov, M.; Herdewijn, P.; Holliger, P. Random-sequence genetic oligomer pools display an innate potential for ligation and recombination. Elife 2018, 7, 43022. [CrossRef]

184. Chang, J.; Taylor, J. In vivo RNA-directed transcription, with template switching, by a mammalian RNA polymerase. EMBO J. 2002, 21, 157-164. [CrossRef]

185. Gudima, S.O.; Chang, J.; Taylor, J.M. Reconstitution in cultured cells of replicating HDV RNA from pairs of less than full-length RNAs. RNA 2005, 11, 90-98. [CrossRef]

186. Rackwitz, H.R.; Rohde, W.; Sänger, H.L. DNA-dependent RNA polymerase II of plant origin transcribes viroid RNA into full-length copies. Nature 1981, 291, 297-301. [CrossRef]

187. Schibler, M.; Piuz, I.; Hao, W.; Tapparel, C. Chimeric Rhinoviruses Obtained via Genetic Engineering or Artificially Induced Recombination Are Viable Only if the Polyprotein Coding Sequence Derives from the Same Species. J. Virol. 2015, 89, 4470-4480. [CrossRef] [PubMed]

188. Woodman, A.; Lee, K.-M.; Janissen, R.; Gong, Y.-N.; Dekker, N.H.; Shih, S.-R.; Cameron, C.E. Predicting Intraserotypic Recombination in Enterovirus 71. J. Virol. 2018, 93, e02057-18. [CrossRef] [PubMed]

189. Holmblat, B. Etudes des Echanges Génétiques entre Poliovirus et Coxsackievirus: Un Modèle d'écosystème, d'évolution et d'émergence Virale. Ph.D. Thesis, Paris Diderot University, Paris, France, 2012.

190. Kuge, S.; Nomoto, A. Construction of viable deletion and insertion mutants of the Sabin strain of type 1 poliovirus: Function of the $5^{\prime}$ noncoding sequence in viral replication. J. Virol. 1987, 61, 1478-1487. [PubMed]

191. Gmyl, A.P.; Pilipenko, E.V.; Maslova, S.V.; Belov, G.A.; Agol, V.I. Functional and genetic plasticities of the poliovirus genome: Quasi-infectious RNAs modified in the 5'-untranslated region yield a variety of pseudorevertants. J Virol 1993, 67, 6309-6316. [PubMed]

192. Baroth, M.; Orlich, M.; Thiel, H.J.; Becher, P. Insertion of cellular NEDD8 coding sequences in a pestivirus. Virology 2000, 278, 456-466. [CrossRef] [PubMed]

193. Bowman, R.R.; Hu, W.S.; Pathak, V.K. Relative rates of retroviral reverse transcriptase template switching during RNA- and DNA-dependent DNA synthesis. J. Virol. 1998, 72, 5198-5206. [PubMed]

194. Poirier, E.Z.; Mounce, B.C.; Rozen-gagnon, K.; Hooikaas, P.J.; Stapleford, K.A.; Moratorio, G.; Vignuzzi, M. Low-Fidelity Polymerases of Alphaviruses Recombine at Higher Rates To Overproduce Defective Interfering Particles. J. Virol. 2016, 90, 2446-2454. [CrossRef]

195. Lazzarini, R.A.; Keene, J.D.; Schubert, M. The origins of defective interfering particles of the negative-strand RNA viruses. Cell 1981, 26, 145-154. [CrossRef]

196. An, W.; Telesnitsky, A. Effects of varying sequence similarity on the frequency of repeat deletion during reverse transcription of a human immunodeficiency virus type 1 vector. J. Virol. 2002, 76, 7897-7902. [CrossRef]

197. Lin, C.-C.; Yang, Z.-W.; Iang, S.-B.; Chao, M. Reduced genetic distance and high replication levels increase the RNA recombination rate of hepatitis delta virus. Virus Res. 2015, 195, 79-85. [CrossRef]

198. Koike, S.; Taya, C.; Aoki, J.; Matsuda, Y.; Ise, I.; Takeda, H.; Matsuzaki, T.; Amanuma, H.; Yonekawa, H.; Nomoto, A. Characterization of three different transgenic mouse lines that carry human poliovirus receptor gene-Influence of the transgene expression on pathogenesis. Arch. Virol. 1994, 139, 351-363. [CrossRef] [PubMed]

199. Nagata, N.; Iwasaki, T.; Ami, Y.; Sato, Y.; Hatano, I.; Harashima, A.; Suzaki, Y.; Yoshii, T.; Hashikawa, T.; Sata, T.; et al. A poliomyelitis model through mucosal infection in transgenic mice bearing human poliovirus receptor, TgPVR21. Virology 2004, 321, 87-100. [CrossRef] [PubMed]

200. Heath, L.; van der Walt, E.; Varsani, A.; Martin, D.P. Recombination Patterns in Aphthoviruses Mirror Those Found in Other Picornaviruses. J. Virol. 2006, 80, 11827-11832. [CrossRef] [PubMed]

201. Twiddy, S.S.; Holmes, E.C. The extent of homologous recombination in members of the genus Flavivirus. J. Gen. Virol. 2003, 84, 429-440. [CrossRef] [PubMed]

202. Agol, V.I.; Gmyl, A.P. Viral security proteins: Counteracting host defences. Nat. Rev. Microbiol. 2010, 8 , 867-878. [CrossRef]

203. Teterina, N.L.; Levenson, E.A.; Ehrenfeld, E. Viable Polioviruses That Encode 2A Proteins with Fluorescent Protein Tags. J. Virol. 2010, 84, 1477-1488. [CrossRef]

204. Sadeuh-Mba, S.A.; Bessaud, M.; Joffret, M.-L.; Endegue Zanga, M.-C.; Balanant, J.; Mpoudi Ngole, E.; Njouom, R.; Reynes, J.-M.; Delpeyroux, F.; Rousset, D. Characterization of Enteroviruses from Non-Human 
Primates in Cameroon Revealed Virus Types Widespread in Humans along with Candidate New Types and Species. PLoS Negl. Trop. Dis. 2014, 8, e3052. [CrossRef]

205. Hellen, C.U.T.; de Breyne, S. A Distinct Group of Hepacivirus/Pestivirus-Like Internal Ribosomal Entry Sites in Members of Diverse Picornavirus Genera: Evidence for Modular Exchange of Functional Noncoding RNA Elements by Recombination. J. Virol. 2007, 81, 5850-5863. [CrossRef]

206. Hu, B.; Zeng, L.P.; Yang, X.L.; Ge, X.Y.; Zhang, W.; Li, B.; Xie, J.Z.; Shen, X.R.; Zhang, Y.Z.; Wang, N.; et al. Discovery of a rich gene pool of bat SARS-related coronaviruses provides new insights into the origin of SARS coronavirus. PLoS Pathog. 2017, 13,1-27. [CrossRef]

207. Kolondam, B.; Rao, P.; Sztuba-Solinska, J.; Weber, P.H.; Dzianott, A.; Johns, M.A.; Bujarski, J.J. Co-infection with two strains of Brome mosaic bromovirus reveals common RNA recombination sites in different hosts. Virus Evol. 2015, 1, vev021. [CrossRef]

208. Shi, M.; Lin, X.D.; Tian, J.H.; Chen, L.J.; Chen, X.; Li, C.X.; Qin, X.C.; Li, J.; Cao, J.P.; Eden, J.S.; et al. Redefining the invertebrate RNA virosphere. Nature 2016, 540, 539-543. [CrossRef] [PubMed]

(C) 2019 by the authors. Licensee MDPI, Basel, Switzerland. This article is an open access article distributed under the terms and conditions of the Creative Commons Attribution (CC BY) license (http://creativecommons.org/licenses/by/4.0/). 